\title{
Business ecosystem architecture development: a case study of Electric Vehicle home charging
}

\author{
Zheng $\mathrm{Ma}^{1 *}{ }^{*}$, Kristoffer Christensen ${ }^{2}$ and Bo Nørregaard Jørgensen ${ }^{2}$
}

\author{
*Correspondence: zma@mmmi.sdu. \\ $\mathrm{dk}$ \\ ${ }^{1}$ SDU Health Informatics and \\ Technology, The Maersk Mc-Kinney \\ Moller Institute, University of \\ Southern Denmark, Odense, \\ Denmark \\ Full list of author information is \\ available at the end of the article
}

\begin{abstract}
Due to the complexity of business ecosystems, the architecture of business ecosystems has not been well discussed in the literature, and modeling or simulation of business ecosystems has been rarely focused. Therefore, this paper proposes a business ecosystem ontology and introduces a methodology for business ecosystem architecture design. The proposed methodology includes five stages: 1) Boundary identification of a business ecosystem; 2) Identification of actors and their roles in the business ecosystem; 3) Identification of actors' value propositions; 4) Identification of interaction between actors; 5) Verification of business ecosystem architecture design. This paper uses the Danish electricity system as an example to introduce the methodology, and use Electric Vehicle home charging as a case study to demonstrate the application of the developed methodology. The case study demonstrates that the proposed methodology is a systematic approach and can be easily applied to any ecosystem architecture design with the five stages, and the designed ecosystem architecture can represent the physical system and business. Several definitions are clarified in the paper, e.g., actor, role, interaction, ecosystem roadmap and expanded/shifted ecosystem, etc. With clear definitions, the proposed methodology provides a visualized, clear structure of behaviors and specifications for a given business ecosystem.
\end{abstract}

Keywords: Business ecosystem, Ecosystem architecture, Architecture design, Ontology, EV charging

\section{Introduction}

Business ecosystem theories have discussed business ecosystem life cycle (Moore 1996), ecosystem roles (Iansiti and Levien 2004; Levien 2004), S-D (Service-Dominant) logic and value co-creation (Vargo and Lusch 2016). However, the architecture of the business ecosystem has not been well discussed in the literature, although the core elements, actors/roles, and interactions have been mentioned. Meanwhile, the modeling or simulation of business ecosystems has been rarely focused due to the complexity of business ecosystems (Ma 2019).

No systematic methodology available for the business ecosystem analysis and architecture design is one of the main challenges to simulate/model a business ecosystem.

(c) The Author(s). 2021 Open Access This article is licensed under a Creative Commons Attribution 4.0 International License, which permits use, sharing, adaptation, distribution and reproduction in any medium or format, as long as you give appropriate credit to the original author(s) and the source, provide a link to the Creative Commons licence, and indicate if changes were made. The images or other third party material in this article are included in the article's Creative Commons licence, unless indicated otherwise in a credit line to the material. If material is not included in the article's Creative Commons licence and your intended use is not permitted by statutory regulation or exceeds the permitted use, you will need to obtain permission directly from the copyright holder. To view a copy of this licence, visit http://creativecommons.org/licenses/by/4.0/. 
Especially, the majority of the literature is either case-based or has only guidelines without details. Meanwhile, the boundary of a given business ecosystem, the definitions of actors and their roles, types of interactions, especially the correlations among the above elements are missing. A business ecosystem ontology can support the business ecosystem architecture investigation, modeling and simulation.

Therefore, this paper aims to follow up the paper 'Business Ecosystem modeling- The Hybrid of System Modeling and Ecological Modeling: An application of the smart grid' (Ma 2019), and introduces 'Part I- Business ecosystem architecture development' which aims to identify a target business ecosystem and its elements (actors, roles, and interactions). A framework for business ecosystem modeling is proposed in (Ma 2019), and the proposed framework includes three parts and nine stages that combine theories from system engineering, ecology, and business ecosystem (shown in Table 1).

This paper firstly discusses the related works of business ecosystem architecture. In the Methodology section, this paper uses the Danish electricity business ecosystem as an example to introduce the five stages in the proposed methodology. The application of State-of-the-Art techniques for investigating existing solutions and their business model is also introduced in the Methodology section; In the Case Study section, a case study of Electric Vehicle home charging in Denmark is introduced to demonstrate the application of the methodology. Definitions clarified in the paper and proposed methodology are summarized in the Discussion and Conclusion sections including the paper contribution and future works.

\section{Related work of business ecosystem architecture}

Manning et al. (2002) propose a general 6-step approach for business ecosystem building. Later, Papert and Pflaum (2017) present a general guideline on ecosystem building for Internet of Things (IoT) Services in Supply Chain Management. However, the two guidelines (shown in Table 2) are for practically visualizing a business ecosystem, not for the business ecosystem architecture development.

Compared to the guidelines proposed by (Manning et al. 2002; Papert and Pflaum 2017), other business ecosystem frameworks focus more on the focal companies' perspective. For instance, Rong et al. (2015) develop a 6C framework (including context,

Table 1 The framework and steps of the business ecosystem modeling (Ma 2019)

\begin{tabular}{|c|c|c|}
\hline Part & Stage & Business ecosystem modeling \\
\hline \multirow{4}{*}{$\begin{array}{l}\text { Part I } \\
\text { Business ecosystem } \\
\text { architecture development }\end{array}$} & 1 & Identify the boundary of a selected ecosystem. \\
\hline & 2 & Identify actors and their roles in the ecosystem. \\
\hline & 3 & Identify actors' value propositions and business models. \\
\hline & 4 & Identify interaction between actors (different types of interactions) \\
\hline \multirow[t]{2}{*}{$\begin{array}{l}\text { Part II } \\
\text { Factor analysis }\end{array}$} & 1 & $\begin{array}{l}\text { Investigate influential factors and their impact on the elements in the } \\
\text { ecosystem (actors, roles, and interaction) }\end{array}$ \\
\hline & 2 & Investigate potential changes in the ecosystem. \\
\hline \multirow{3}{*}{$\begin{array}{l}\text { Part III } \\
\text { Ecosystem simulation and } \\
\text { reconfiguration }\end{array}$} & 1 & $\begin{array}{l}\text { Multi-agent based ecosystem modeling to identify ecosystem reaction } \\
\text { towards the potential changes. }\end{array}$ \\
\hline & 2 & $\begin{array}{l}\text { Ecosystem reconfiguration (including reconfiguration of actors, roles, } \\
\text { and interaction) due to changes, system dynamics modeling might be } \\
\text { applied at this stage. }\end{array}$ \\
\hline & 3 & Business model reconfiguration. \\
\hline
\end{tabular}


Table 2 Two guidelines for practically visualizing a business ecosystem

\begin{tabular}{ll}
$\begin{array}{l}\text { Demand-driven: } 6 \text { steps to building an ecosystem } \\
\text { of demand for your business (Manning et al. 2002) }\end{array}$ & $\begin{array}{l}\text { Development of an Ecosystem Model for the } \\
\text { Realization of Internet of Things (loT) Services in } \\
\text { Supply Chain Management (Papert and Pflaum } \\
\text { 2017) }\end{array}$ \\
\hline $\begin{array}{ll}\text { 1. Understand customer demand by mapping your } \\
\text { customer ecosystem. }\end{array}$ & $\begin{array}{l}\text { 1. Definition of an loT service that should be realized; } \\
\text { 2. Leverage ecosystem partners to take advantage of } \\
\text { indirect demand. }\end{array}$ \\
$\begin{array}{ll}\text { 3. Build adaptive strategies to become demand-driven } \\
\text { realization of the defined loT service; }\end{array}$ & $\begin{array}{l}\text { 3. Identification of necessary roles that provide the } \\
\text { remaining value contributions for the realization of the } \\
\text { defined loT service, in relation to the presented } \\
\text { ecosystem model; }\end{array}$ \\
$\begin{array}{ll}\text { 4. Use information technology to support your } \\
\text { ecosystem. }\end{array}$ & $\begin{array}{l}\text { 4. Establishment of the own ecosystem by building up } \\
\text { represent the necessary roles (cooperation partners) } \\
\text { for the provision of the remaining value contributions; }\end{array}$ \\
5. Turn business processes into ecosystem capabilities. & $\begin{array}{l}\text { 5. Negotiations with the cooperation partners about } \\
\text { compensation (remuneration) for the provision of the } \\
\text { remaining value contributions; }\end{array}$ \\
6. Synchronize customer ecosystem and supply chain. & $\begin{array}{l}\text { 6. Realization of the identified loT service in } \\
\text { cooperation with the partners of the own ecosystem. }\end{array}$
\end{tabular}

cooperation, construct, configuration, capability, and change) for the understanding of IoT-based business ecosystems with six case studies.

The Business Ecosystem Architecture Modeling (TEAM) is proposed by (Wieringa et al. 2019) aims to 'map the architecture of the ecosystem to the required technical infrastructure', with the application of the e3-value method (https://research.e3value. $\mathrm{com} /$ ) to model the value exchange among participants, e.g. value network of an electricity ecosystem. This framework specifically focuses on coopetition from a focal company's perspective, and doesn't focus on the ecosystem perspective or actors' roles, and the interactions are not mentioned. Meanwhile, it is difficult to design a complex business ecosystem with the e3-value method due to its restriction.

The methodology of Business Ecosystem Network Analysis (MOBENA) developed in (Battistella et al. 2013) includes four analysis steps and defines three types of players: macro-classes of actors, classes/categories of actors and main players. It also classifies links (Connections Matrix) with four levels (no relation; intangible relation; tangible relation; and possible future relation). This methodology mainly focuses on the network perspective and the detailed actor, their roles and interactions are not included.

Similarly, a four-stage process for analyzing business ecosystem dynamics is presented in (Basole et al. 2015) and also focuses on the network perspective of the business ecosystem. The four stages include: boundary specification (nodes, node types, relationship types and specifying the desired analysis timeframe are determined); Metrics identification (ecosystem and node levels); Computation, analysis, and visualization (with bicentric ecosystem layout by the tabular representations); and Sensemaking and storytelling; Boundary Specification.

Four basic elements with two perspectives of the ecosystem structure are defined in (Adner 2016). The four elements include activities, actors, positions and links, and the two perspectives include ecosystem-as-affiliation and ecosystem-as-structure approaches. An ecosystem architecture is proposed in (Adner 2016), however, the 
ecosystem architecture is a blueprint of a software system, not an architecture overview of a business ecosystem.

Similarly, a decentralized business ecosystem model is discussed by (Radonjic-Simic and Pfisterer 2019) from the perspective of complex products and the four elements of activities, actors, positions, and links. However, it is difficult to follow the methods provided by (Adner 2016; Radonjic-Simic and Pfisterer 2019) due to the missing correlation among elements, although elements and some sub-elements (e.g three types of activities and six types of roles for actors) are introduced and defined in the ecosystem structure.

'Links' are described as 'specify transfers across actors', and 'need not have any direct connection to the focal actor' in (Adner 2016). Comparatively, 'links' are described as 'how actors need to interact with each other' in (Radonjic-Simic and Pfisterer 2019). However, both descriptions do not include a detailed explanation of the interaction types and contents. Some literature has used value flows to describe the interaction between actors, e.g. four types of flows (value flow, fund flow, logistics, and cooperation) are stated in (Zhang et al. 2016), but without description.

A business ecosystem modeling with the combination of natural ecosystems and multi-agent systems is proposed by (Marín et al. 2007). However, only two types of agents (supplier and customer) are proposed which can not provide a holistic understanding of the business ecosystem architecture. Similar to (Marín et al. 2007), a service ecosystem (consumers, service provider, and competition) with a multi-agent system is investigated in (Tian et al. 2008). Although the interactions among entities are introduced in (Tian et al. 2008), the detailed discussion on the roles' interactions is missing.

Overall, the business ecosystem structure and analysis have been discussed in the literature, but no systematic approach has been proposed. A systematic approach should not only provide a guideline or visualization with specific aspects, but also be used for further ecosystem analysis and preparation of simulation and modeling. Meanwhile, although the fundamental elements of business ecosystems have been discussed in the literature, a clarification is missing, especially the correlation between elements, e.g. actors and roles, types of value flows, etc.

\section{Methodology of business ecosystem architecture development}

The proposed methodology of business ecosystem architecture includes five stages and three State-of-the-Art techniques are recommended to be applied at the early stages.

\section{Stage 1- Boundary identification of a business ecosystem}

Based on the business ecosystem definition, it is important to define the 'area/a community' at the beginning of the business ecosystem architecture design. An ecosystem boundary is necessary to be precisely described since the related stakeholders, their interactions may be different for different purposes. For example, energy flexibility and demand response are popularly discussed in the energy field. Many countries and associations have announced initiatives, policies, and regulations, e.g., aggregation market, tariffs for the distributed energy resources, etc. to support the execution. However, energy flexibility and demand response have two different definitions. For instance, Demand response is defined by the European Commission as "voluntary changes by 
end-consumers of their usual electricity use patterns-in response to market signals" (Laursen 2017). Energy flexibility in the smart grid can happen among the whole electricity system, e.g. flexibility from the production, from the market (e.g. regulating market), from the grid (large scale battery), and from the consumption side. Therefore, the ecosystem boundary should be defined according to the focuses.

The boundary of a selected business ecosystem can be defined with two dimensions:

- Targeted domain: is defined by the primary supply chain, main business, and related markets. It aims to identify 'what' and 'who' of the business ecosystem. E.g., the electricity grid and district heating network are two different targeted domains, the business and stakeholders are different (Ma et al. 2020).

- Cultural/geographic boundary: aims to identify 'where' and 'how' of the ecosystem. E.g. the Danish electricity grid complies with Danish regulation.

Three elements are introduced at Stage 1 for the understanding of a selected business ecosystem:

- Primary supply chain

- Main business

- Markets

According to the Cambridge dictionary, the definition of the value chain is: 'the series of companies involved in the different stages of producing a product or service that is sold to consumers, with each stage adding to its value' and the definition of 'supply chain' is: 'the system of people and organizations that are involved in getting a product from the place where it is made to customers'. Meanwhile, the definitions of 'value' or 'value-added' in the dictionary are not clear compared to 'supply'. However, business ecosystem modeling sometimes only focuses on the in-house process, e.g. energy flexibility in commercial greenhouses (Ma et al. 2018) or buildings (Ma et al. 2017a). Therefore, this paper recommends using 'supply chain' instead of 'value chain' due to the clear definition of the stakeholders' roles and relations, although supply chain mainly refers to the chain from the production to the end-users according to the definition. Meanwhile, the supply chain in the business ecosystem modeling should represent either a production process or a whole supply chain based on individual situations.

Quite often a selected business ecosystem includes several supply chains from a domain perspective, e.g., the sector coupling. Therefore, it is important to identify the primary supply chain in the selected business ecosystem. For instance, the business ecosystem of electric vehicle-to-grid includes two supply chains: the supply chain of electric vehicles and the supply chain of electricity. Therefore, it is important to identify the main supply chain and the secondary supply chain at this stage based on the focuses in different cases.

Supply chains only provide a linear illustration of how a product/service is supplied, the trading or financial aspect is missing. Therefore, the main business and markets are essential to be considered for a holistic understanding of a business ecosystem. For instance, in an unbundled electricity business ecosystem, e.g. the Nordic electricity business ecosystem, all trading goes through markets, e.g. the wholesale market, the 
regulating markets, and the retail markets (Ma et al. 2016). Many stakeholders in this business ecosystem are not shown in the supply chain and only can be illustrated from the market perspective. For example, the electricity suppliers are the retailers that sell electricity to consumers, however, it is the distribution system operators that deliver electricity to consumers.

- Example of the Danish electricity system

The overall supply chain of the Danish electricity system is outlined in Fig. 1 which shows the electricity supply chain from the extraction of fuels to the end-use of electricity, consisting of electricity generation, transmission, distribution, and consumption. In the past, many EU countries had a boundling market regulation that allowed utilities to own all parts of the electricity supply chain, from the production, transmission, distribution to retail (Mlecnik et al. 2019). Today, the electricity sector in Denmark is liberalized as under the EU regulation, and there is an unbundling between natural monopolies (transmission and distribution network) and entities that are subject to the competition (electricity production and trade) (European Comission 2012). The transmission grids operate at $400 \mathrm{kV}$ and $150 / 132 \mathrm{kV}$ (150 and $132 \mathrm{kV}$ is for DK-West and DK-East, respectively), and are owned and operated by the Danish Transmission System Operator (TSO)- Energinet. The distribution grids operate at 60/50, 10, and $0.4 \mathrm{kV}$ are operated by the Distribution System Operators (DSOs).

The market framework consists of electricity trading which includes different electricity markets, market players, and market regulations. The Danish electricity market is comprised of a wholesale market and a retail market. The Danish wholesale market is an integral part of the free Nordic electricity market (shown in Fig. 2). Both Danish and EU authorities have supported liberalization to stimulate free competition in electricity production and trade. The wholesale market trades via the Nord Pool spot market, which facilitates trade between producers and traders (Energinet 2019a).

\section{Stage 2- Identification of actors and their roles in the business ecosystem}

Stakeholders in the business ecosystem have been discussed since the introduction of the business ecosystem. The majority of the literature regarding stakeholders in the business ecosystem has focused on the types of ecosystem roles, e.g. dominator, keystone, and niche firms (Levien 2004). However, approaches for identifying stakeholders and their roles are rarely discussed.

Meanwhile, it is necessary to give clear definitions of 'stakeholder', 'actor', and 'role', as each field, e.g., business ecosystem, system architecture, or ecology has its way to use these terms as discussed in (Ma 2019). For clarification, this paper defines the related terms as:

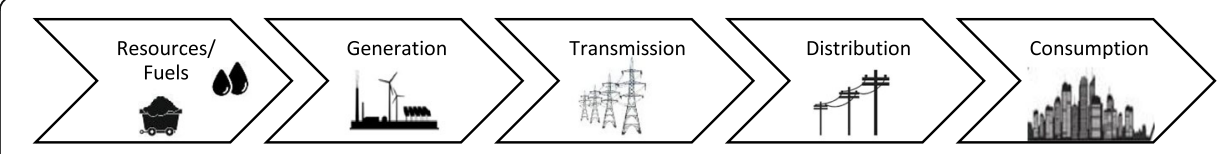

Fig. 1 The electricity supply chain 


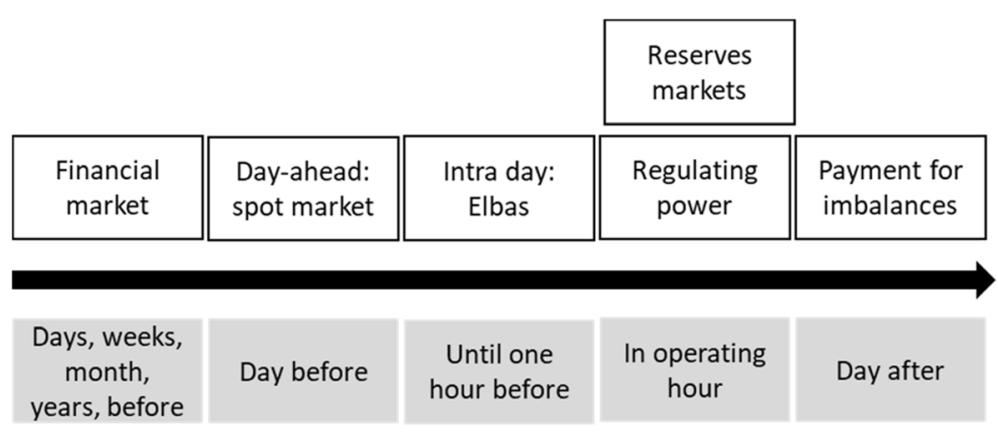

Fig. 2 Nordic electricity wholesale market structure (Ea Energy Analyses 2012)

- Stakeholder: any individual, company, organization, agency, or institution who has an interest in or influence the business ecosystem, e.g., regulatory authorities.

- Actor: type of stakeholders who directly participate in the ecosystem's value creation process, e.g., consumers.

- Role: actor's responsibility in the business ecosystem, e.g., transport electricity in distribution grids.

According to these definitions, this paper uses the term 'actor' instead of 'stakeholder' in the business ecosystem architecture design, and each actor can have multiple roles (1:n). In some cases, one role can be assigned to multiple actors, but it rarely happens. The relation between role and actor is defined similarly to the definition in the SGAM framework (CEN-CENELEC-ETSI Smart Grid Coordination Group 2014), but differently from the Harmonized electricity market role model (ENTSO-E 2018), because the definitions of actors and roles in (Smart Grid Coordination Group 2014) can better represent the relations between actors and roles in a smart grid.

This paper recommends using: a) primary supply chain, b) main business and c) markets that are identified in Stage 1 to identify roles and their correlated actors in a business ecosystem (e.g. shown in Tables 3 and 4). If it is necessary, the actors and their roles involved in the secondary supply chain should be considered.

It is easier to identify roles first rather than actors because there are legal requirements for the responsibilities in the supply chain and markets that actors need to comply with. Through regulations, roles are assigned to actors. For instance, the responsibility for transporting electricity in and maintaining the transmission grids is called TSO, and the required responsibility for the wholesale market operation is the market operator. However, the actor who conducts both roles is the TSO that is assigned through the Nordic electricity regulations. An example of the identified main actors and their roles in the Danish electricity business ecosystem is shown in Table 5.

Table 3 Roles and actors in the Danish electricity supply chain

\begin{tabular}{lll}
\hline Supply chain segment & Role & Actor \\
\hline Generation & Electricity producer & Electricity producer \\
Transmission & Transmission system operator (TSO) & TSO \\
Distribution & Distribution system operator (DSO) & DSO \\
Consumption & Electricity consumer & Domestic consumer \\
\hline
\end{tabular}


Table 4 Roles and actors in the Danish electricity markets

\begin{tabular}{lllll}
\hline Market & Sub-market & $\begin{array}{l}\text { Market } \\
\text { segment }\end{array}$ & Role & Actor \\
\hline $\begin{array}{llll}\text { Wholesale } \\
\text { market }\end{array}$ & $\begin{array}{l}\text { Day-ahead and Intraday } \\
\text { markets }\end{array}$ & Market operation & Market operator & TSO \\
& & Market & Electricity producer & Electricity producer \\
& & & Electricity retailer & Electricity supplier \\
& & Balance responsible & Balance responsible \\
& & party & party \\
& \multirow{2}{*}{ Reserves market } & Market operation & Market operator & TSO \\
& & Market & Electricity producer & Electricity producer \\
& & participation & Balance responsible & Balance responsible \\
& & & party & party \\
Retail market & N/A & Electricity retailer & Electricity supplier \\
& & & Electricity consumer & Electricity consumer \\
\hline
\end{tabular}

To further understand actors in an ecosystem, the population of each actor is recommended to be investigated. For instance, there is only one TSO, 48 DSOs, 59 electricity retailers, and 46 BRPs (Balance responsible parties) in Denmark (see the Appendix for the details).

\section{Stage 3- Identification of actors' value propositions}

This stage is usually conducted parallel together with stage 2, because actors' value propositions can be figured out once the actors and their roles are identified. One role should be correlated to one value proposition and usually together with a business model. If an actor has several value propositions, each value proposition should be assigned to a role. For instance, the actors' value propositions can be summarized in Table 6 according to the description of the roles \& responsibilities in the Danish electricity market by Energinet (who is responsible for the operation of the transmission grid and the electricity system in Denmark). The potential interactions between roles in a business ecosystem can be identified at this stage.

\section{Stage 4- Identification of interaction between actors}

One key element in the business ecosystem is the interaction between actors (Moore 1996), and actors interact for value co-creation and co-evolution (Rong and Shi 2015; Tanev et al. 2010). The types of interactions have been discussed as flows of matter,

Table $\mathbf{5}$ The identified main actors and their roles in the Danish electricity business ecosystem

\begin{tabular}{ll}
\hline Actor & Role \\
\hline Electricity producer & Electricity producer \\
TSO & Transmission system operator (TSO) \\
& Market operator \\
DSO & Distribution system operator (DSO) \\
Electricity consumer & Electricity consumer \\
Electricity supplier & Electricity retailer \\
Balance responsible party & Balance responsible party (BRP) \\
\hline
\end{tabular}


Table 6 Actors, roles, and their value propositions described in the Danish electricity business ecosystem (modified from (ENTSO-E 2018; Energinet 2020a))

\begin{tabular}{|c|c|c|}
\hline Actor & Role & Value proposition \\
\hline \multirow{2}{*}{$\begin{array}{l}\text { Electricity } \\
\text { producer }\end{array}$} & \multirow[t]{2}{*}{ Electricity producer } & Generate electricity \\
\hline & & Sell the electricity generated at the plant into the electricity markets \\
\hline \multirow[t]{6}{*}{ TSO } & \multirow{3}{*}{$\begin{array}{l}\text { Transmission system } \\
\text { operator (TSO) }\end{array}$} & Operate the transmission grid \\
\hline & & Security of supply \\
\hline & & Ensuring the balance between consumption and generation \\
\hline & \multirow[t]{3}{*}{ Market operator } & Set the framework for a well-functioning electricity market \\
\hline & & Ensures fair prices for both consumers and producers \\
\hline & & Promotes climate-friendly energy solutions \\
\hline \multirow[t]{6}{*}{ DSO } & \multirow[t]{3}{*}{$\begin{array}{l}\text { Distribution system } \\
\text { operator (DSO) }\end{array}$} & $\begin{array}{l}\text { Own the electricity networks from the transmission grid to the } \\
\text { consumers. }\end{array}$ \\
\hline & & $\begin{array}{l}\text { Operate the network tasks, such as the connection of new customers, } \\
\text { specification of electricity consumption, development and } \\
\text { maintenance of the physical plants }\end{array}$ \\
\hline & & $\begin{array}{l}\text { Responsible for a number of ad hoc tasks, such as re-establishment of } \\
\text { live cables that have been damaged and establishment of live cable } \\
\text { at new plants }\end{array}$ \\
\hline & \multirow[t]{2}{*}{ Metered data collector } & Measure consumption and generation of electricity in their grid area \\
\hline & & $\begin{array}{l}\text { Collect, validate, send, and receive meter data can be delegated to } \\
\text { independent metering point administrators }\end{array}$ \\
\hline & $\begin{array}{l}\text { Tax payment } \\
\text { responsible }\end{array}$ & $\begin{array}{l}\text { Responsible for payment of electricity taxes to SKAT (central Danish } \\
\text { tax administration) of the amount of electricity consumed in the grid } \\
\text { area. }\end{array}$ \\
\hline $\begin{array}{l}\text { BRP for } \\
\text { consumption }\end{array}$ & BRP for consumption & $\begin{array}{l}\text { Buy and sell electricity at the Nord Pool Spot market on behalf of } \\
\text { electricity suppliers and plant owners }\end{array}$ \\
\hline $\begin{array}{l}\text { BRP for } \\
\text { production }\end{array}$ & BRP for production & $\begin{array}{l}\text { On a daily basis, submit plans to Energinet regarding the electricity } \\
\text { expected to be generated and consumed in the next } 24 \mathrm{~h} \text { by the }\end{array}$ \\
\hline \multirow{2}{*}{ BRP for trade } & \multirow{2}{*}{ BRP for trade } & \\
\hline & & $\begin{array}{l}\text { Are financially responsible to Energinet for imbalances between } \\
\text { expected and actual generation and consumption on the day of } \\
\text { operation. The cost of the imbalance is invoiced by Energinet to the } \\
\text { balance responsible players who are responsible for the imbalances }\end{array}$ \\
\hline \multirow{6}{*}{$\begin{array}{l}\text { Electricity } \\
\text { supplier }\end{array}$} & \multirow[t]{6}{*}{ Electricity retailer } & The customers' primary contact with the electricity system \\
\hline & & $\begin{array}{l}\text { Responsible for customer information in DataHub is correct (e.g. } \\
\text { electricity suppliers register the changes of customers and changes to } \\
\text { customer relations at metering points) }\end{array}$ \\
\hline & & $\begin{array}{l}\text { Buy electricity through a balance responsible party at Nord Pool Spot } \\
\text { or directly from plant owners and sell it to the customers. }\end{array}$ \\
\hline & & $\begin{array}{l}\text { Are obliged to supply all household customers with electricity with a } \\
\text { payment }\end{array}$ \\
\hline & & $\begin{array}{l}\text { Collect payment for both consumption, duties, tariffs, and transport at } \\
\text { the customer in one single invoice }\end{array}$ \\
\hline & & $\begin{array}{l}\text { Pay DSOs for transporting electricity to the customers and to transmit } \\
\text { meter data for settlement purposes. Register payment for } \\
\text { consumption on the metering points into the DataHub }\end{array}$ \\
\hline \multirow{2}{*}{$\begin{array}{l}\text { Electricity } \\
\text { consumer }\end{array}$} & \multirow[t]{2}{*}{ Electricity consumer } & Buy electricity from the electricity supplier. \\
\hline & & $\begin{array}{l}\text { Pay consumption including all duties and taxes, subscriptions, tariffs, } \\
\text { etc. to the electricity supplier. }\end{array}$ \\
\hline
\end{tabular}

energy, or information in ecology (Bousquet and Le Page 2004); information and transaction flows in a business ecosystem (Iyawa et al. 2016); information and energy flows for smart grid (Wolsink 2012). To unify the definitions and types of interaction 
between actors in a business ecosystem, five interaction types and four flow types are proposed in business ecosystem architecture design: goods (products \& services), monetary value, information, data, and intangible value (shown in Table 7). Intangible value is defined as a type of interaction (each interaction happens between two actors/ subjects), but not value flow because it does not move (via interaction) into one direction continuously.

Table 4-Roles and actors in the Danish electricity markets shows that actors do not always directly interact with each other, but via an interface, e.g. market, platform, network, or meters. The 'domains' of the electricity market is defined in the harmonized electricity market role model (ENTSO-E 2018) as 'a delimited area that is uniquely identified for a specific purpose and where energy consumption, production, or trade may be determined'. However, the term 'domain' is used in different ways based on different subjects. Therefore, the term 'object' is introduced in this paper to represent the non-actors in a business ecosystem. For instance, the objects in the electricity business ecosystem are shown in Table 8.

At Stage 3, the investigation results of the value propositions are usually together with their business models which are mainly related to the value flows. Based on the results from Stage 3 and defined interactions, flows and objects, the interactions in the Danish electricity business ecosystem are shown in Table 9. It is easier to list the actors in the interaction table based on the main supply chain.

\section{Stage 5- Verification of business ecosystem architecture design}

Two steps are recommended to verify the designed business ecosystem architecture:

- Design of minimum viable ecosystem, ecosystem roadmap, and transition stages

- Completeness checking of value flows and interactions

\section{Design minimum viable ecosystem, ecosystem roadmap, and transition stages}

Although there are three markets (day-ahead, intra-day, and regulating markets) in the Nordic electricity wholesale market (as shown in Fig. 2), only one marketplace (wholesale market) is illustrated in Table 9 because the focus of the architecture design is the

Table 7 Flows and interactions in the business ecosystem

\begin{tabular}{lll}
$\begin{array}{l}\text { Type of } \\
\text { interaction }\end{array}$ & Type of flow & Description \\
\hline $\begin{array}{l}\text { Goods (Product } \\
\text { \& Service) }\end{array}$ & $\begin{array}{l}\text { Goods (Product } \\
\text { \& Service) }\end{array} \quad \begin{array}{l}\text { The basic products of an economic system that consist of tangible } \\
\text { consumable items (products) and tasks performed by individuals } \\
\text { (service) }\end{array}$ \\
Monetary value & Monetary value & $\begin{array}{l}\text { The amount of value an item or a service has in relation to if it is } \\
\text { sold for cash to a buyer }\end{array}$ \\
Information & Information & $\begin{array}{l}\text { Data that has been processed, organized, structured or presented } \\
\text { to make it useful in a given context }\end{array}$ \\
Data & $\begin{array}{l}\text { Raw, unorganized measurements and facts that need to be } \\
\text { processed to become useful }\end{array}$ \\
Intangible value & $\begin{array}{l}\text { Something that exists but cannot be exactly described, or given an } \\
\text { exact value. }\end{array}$
\end{tabular}


Table 8 The objects in the electricity business ecosystem

\begin{tabular}{|c|c|c|}
\hline Object & Type & Description \\
\hline Marketplace & $\begin{array}{l}\text { - Wholesale marketplaces (Day- } \\
\text { ahead, Intraday, regulating) } \\
\text { - Retail marketplace }\end{array}$ & $\begin{array}{l}\text { The market operations possible along the energy conversion } \\
\text { chain, e.g. energy trading, mass market, retail market (CEN- } \\
\text { CENELEC-ETSI Smart Grid Coordination Group 2012). }\end{array}$ \\
\hline DataHub & $\begin{array}{l}\text { - Data store } \\
\text { - Data exchange }\end{array}$ & $\begin{array}{l}\text { Every piece of information about the electricity consumption } \\
\text { of Danish consumers is stored in DataHub, which also handles } \\
\text { business processes, such as change of address, change of } \\
\text { supplier, etc. (Energinet } 2020 \mathrm{~b} \text { ) }\end{array}$ \\
\hline Grid area & $\begin{array}{l}\text { - Transmission grid } \\
\text { - Distribution grid }\end{array}$ & $\begin{array}{l}\text { The delimited physical area where consumption, production, } \\
\text { and exchange of electricity can be metered. }\end{array}$ \\
\hline Meter point & $\begin{array}{l}\text { - Production metering point } \\
\text { - Consumption metering point }\end{array}$ & $\begin{array}{l}\text { The metering point where energy (one or more production } \\
\text { facilities or consumption units) is measured. }\end{array}$ \\
\hline
\end{tabular}

Danish energy system not the Nord Pool spot market. Meanwhile, some relations, e.g., information sent by BRPs for production to DataHub, are not included. However, it does not influence the ecosystem architecture or the scope of the modeling, although the information above is not presented.

Therefore, it is necessary to only select the necessary actors, roles, and their relations for the ecosystem architecture design within the boundary identified at Stage 1. The concept of the Minimum Viable Ecosystem (MVE) can be applied to serve this purpose. MVE proposed by Adner (Adner 2012) is defined as "the smallest configuration of elements that can be brought together and still create unique commercial value". However, due to the unclear definition of 'value' in this MVE definition, this paper proposes a new definition of the MVE with the consideration of the architecture perspective:

Minimum viable ecosystem Is a completed ecosystem with minimum elements (actors, roles, and interactions), but still can serve the identified ecosystem boundary.

The MVE architecture design is usually for understanding the current (or focused) business ecosystem, and the next step is the future (or boundary expanded/shifted) business ecosystem architecture design that can reflect the progressive plannings and future scenarios. There are different actors, roles, and relations in the MVE and future (or boundary expended/shifted) business ecosystem. For instance, compared to the Danish distribution network ecosystem, several actors, roles, and interactions are added once the boundary is expanded to including the transmission grid (shown as text in blue in Table 9). One future scenario is that consumers become prosumers (producer+ consumer) (Ma et al. 2015). In this future ecosystem, there will be some new actors, roles, interactions, and roles and interactions changed/moved from one actor to another actor.

Therefore, this paper proposes the concepts of 'expanded/shifted ecosystem', 'ecosystem roadmap', and 'transition stage' for the business ecosystem architecture design with the consideration of the future (or boundary expanded/shifted) scenarios:

Expanded/shifted ecosystem Is a completed and minimum ecosystem that expands/ shifts from the previous ecosystem (e.g., MVE) with added elements to service an expanded/shifted ecosystem boundary. 


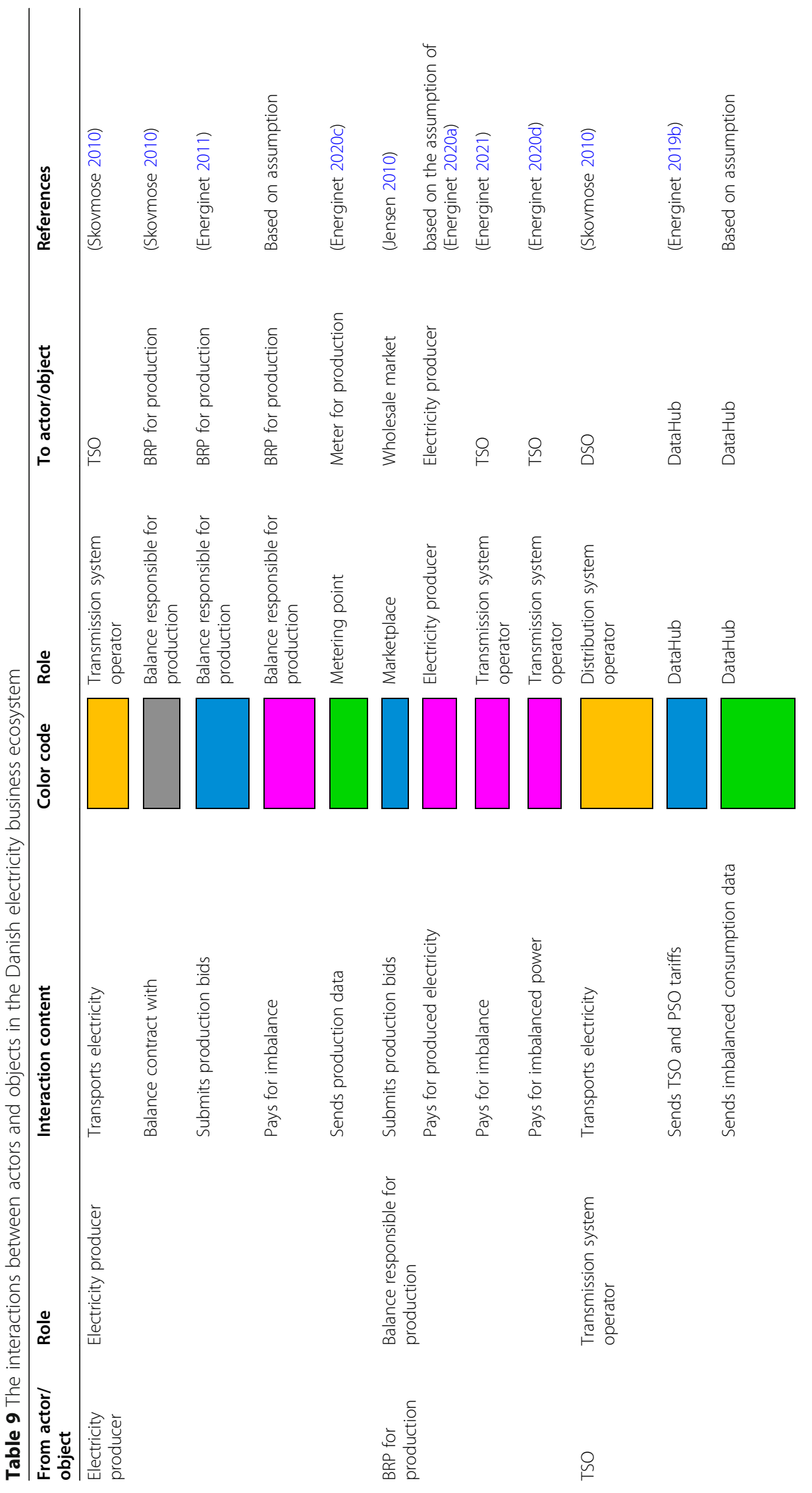




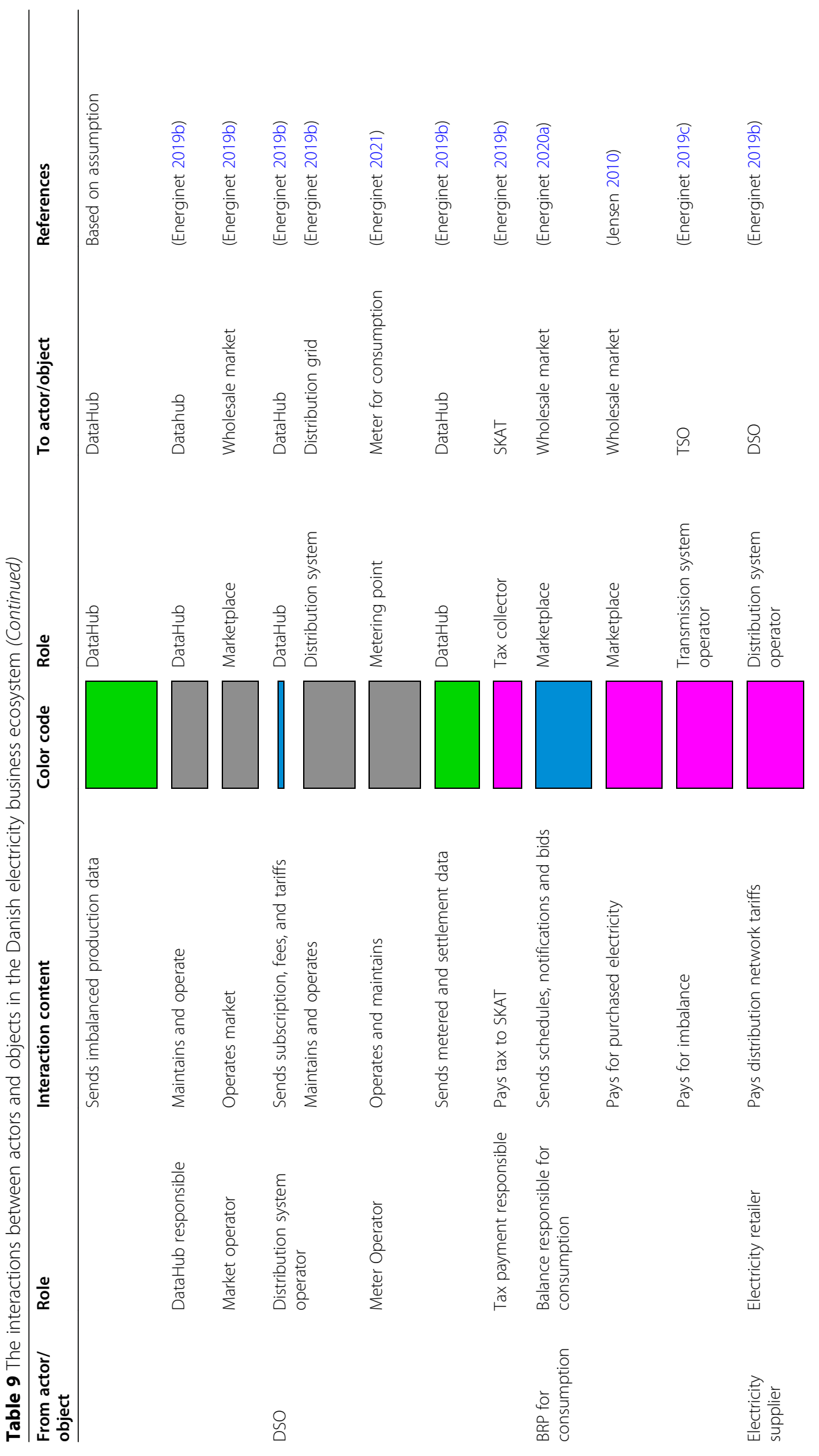




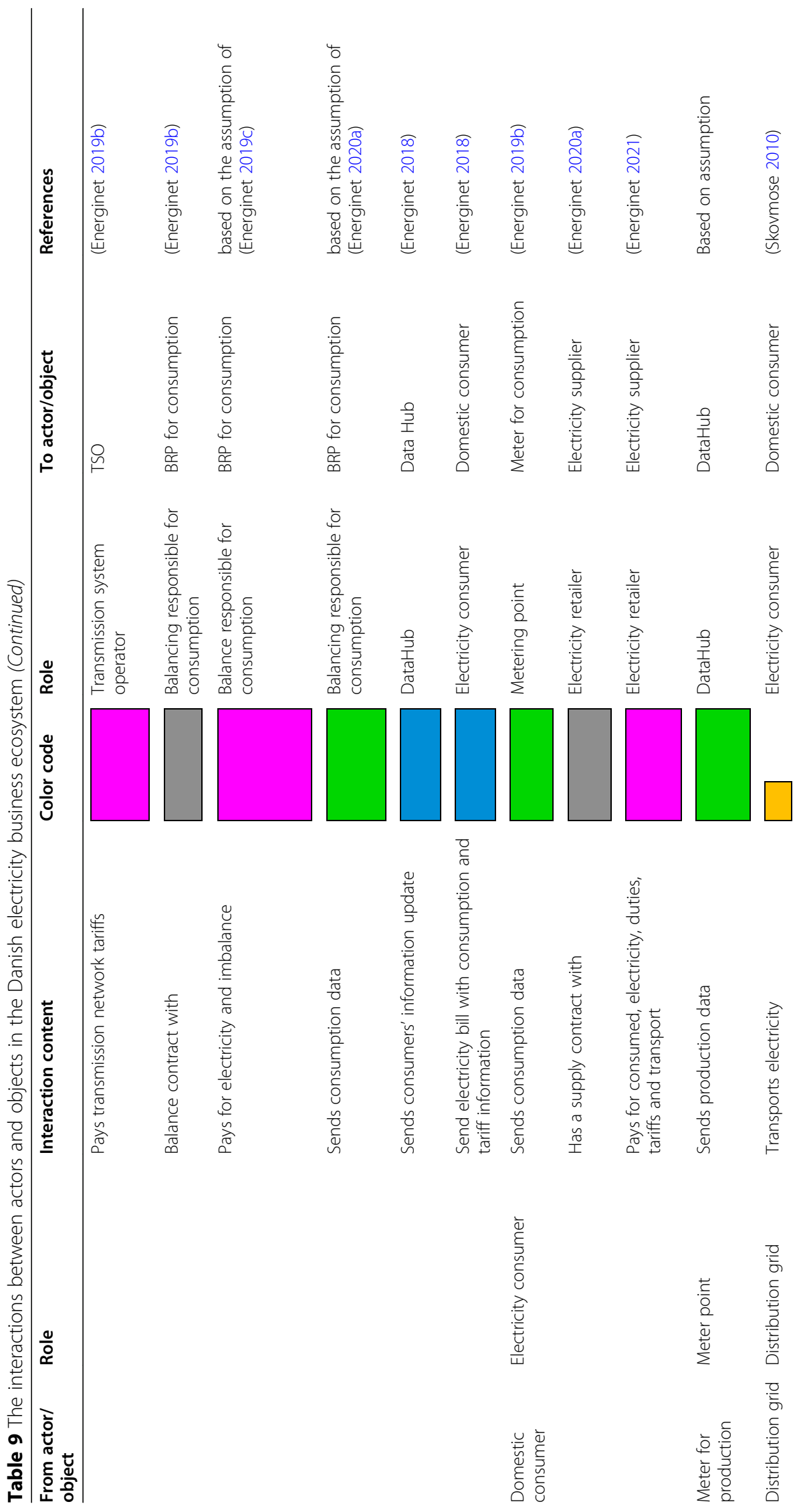




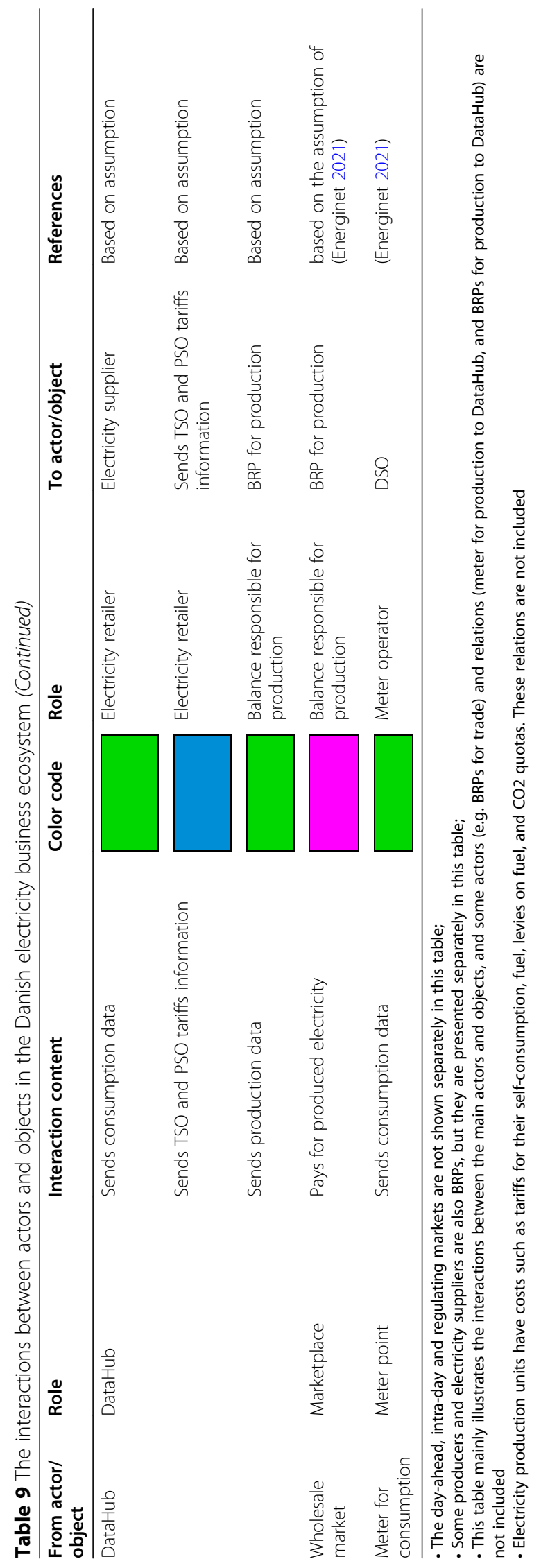


Ecosystem roadmap Is a critical path with sequenced ecosystem transition stages for achieving the planned/future ecosystem.

Transition stage One MVE or expanded/shifted ecosystem is designed at one transition stage. The sequence of the transition stages can be either horizontal (boundary scale) dependent on the boundary coverage or vertical (time scale) dependent on the realization terms (short, medium, and long terms).

By designing the MVE, the minimum but completed ecosystem can match the ecosystem boundary requirement, and at the same time, reduce the complexity of the ecosystem architecture. If MVE is not the final ecosystem, an ecosystem roadmap with transition stages and corresponded expanded/shifted ecosystems can serve the purpose. At each transition stage, whether the ecosystem is expanded or shifted depends on the ecosystem roadmap. The expansion is usually related to the cultural/geographic boundary, and the shifting happens when the targeted domain (one dimension of the ecosystem boundary) changes.

\section{Completeness checking of value flows and interactions}

Although the MVE architecture design can reduce the complexity, the completeness of the designed ecosystem architecture should be verified. The completeness can be verified by checking the completeness of individual value flows. A value flow is defined as 'a specific type of value moves (via interaction) into one direction continuously' in this paper, and the completeness of a value flow means that the value is continuous from the start points to the endpoints.

As explained at Stage 4, the intangible value is defined as a type of interaction but not value flow because it does not move into one direction continuously. However, there are actors and objects in an ecosystem, and an object, e.g. the distribution network can not make any decision. It is the actors who have the responsibility of the object (e.g., operate and maintain) to take actions. Therefore, the completeness of the intangible value interactions between objects and actors needs to be checked.

A business ecosystem mapping is recommended for visualizing and verifying the designed ecosystem architecture. It especially supports the completeness checking of the four individual value flows and the intangible value interactions between objects and actors.

\section{State-of-the-art techniques}

At Stage 3, actors' roles, value propositions are identified. Actors and their responsibilities in the Danish energy system (electricity and district heating) are relatively well described due to the regulation. Actors and their responsibilities in other business ecosystems might be not so clearly described, e.g., building automation (Ma et al. 2017b). Therefore, state-of-the-art techniques are recommended during the whole business ecosystem architecture design, including the investigation of actors, their roles, and value propositions, and their business models in a given market.

The state-of-the-art techniques include market research, literature review, and patent searching. The literature review is conducted by searching databases for scientific articles and statistics \& market reports. For instance, the databases of ACM (Association for Computing Machinery) Digital Library and IEEE (Institute of Electrical and 
Electronics Engineers) Xplore are two popular scientific databases for searching technologies. Market research is usually conducted by desktop research including internet search by using search engines or domain expert consultation (e.g. interviewing related companies and market reports). Market research and literature review cover the developed solutions or the proof of concept, and patent search can identify potential solutions. For instance, to investigate the patents related to the Danish electricity market, a patent search can be conducted by searching Espacenet (the European Patent Office). Market research is the most common state-of-the-art technique applied in the whole business ecosystem architecture design.

\section{Case study and results: electric vehicle home charging in Denmark}

The adoption of electric vehicles (EVs) is an important part of the Danish energy transition towards a fossil independent society. Large-scale plug-in EVs will directly impact the distribution grids. EV charging will not only create higher electricity demand but also high penetration to the grids. The corresponded business ecosystem architecture is designed to investigate the impacts of EV home charging on the distribution grids.

The market research investigation regarding the electricity supply and the distribution grids in Denmark is found by the investigation of the electricity regulation and description via related authorities' websites and reports. The market analysis for EV charging solutions is conducted by internet searching, e.g. using the search engine Google for EV home charging providers in Denmark. For each EV home charging provider, its business model is identified by investigating its webpages. Based on the market research investigation and the proposed methodology, the business ecosystem architecture is developed through the following five stages:

\section{Stage 1- Boundary identification of the business ecosystem}

EV charging can happen at charging stations, parking spaces, and homes. The impacts of different EV charging approaches on the electricity grids are different. To reduce the complexity, only EV charging at home is considered in this case study. Although plenty of literature has discussed the potentials of Viechle-to-Grid (EV as batteries to be recharged back to the grid), the market potentials and feasibility are unclear. Therefore, only EV charging is considered in this case.

There are two supply chains related to EV home charging: electricity supply and EV charging. The main purpose of this case study is to investigate how the distribution network is impacted by EV home charging. Therefore, the primary supply chain is the electricity supply in the distribution grid, and the secondary supply chain is the EV home charging.

There are several markets and businesses related to this business ecosystem: electricity retail market, business for EV sales and EV charging box sales, and EV home charging. Because EV and EV charging box sales are one-time business and not strongly related to the main purpose of the case study, these two businesses are disregarded.

\section{Stage 2- Identification of actors and their roles in the business ecosystem}

The related actors and roles for the electricity supply chain in the distribution grid are similar to Table 9, but some actors and roles that are not directly related to the case 
are excluded. Related actors and their roles for the EV home charging energy ecosystem are shown in Table 10. The list of EV suppliers (bilmagasinet.dk 2019) and chargingbox suppliers in Denmark is shown in Table 11 based on market research.

\section{Stage 3- Identification of actors' value propositions}

This case study only focuses on EV home charging, therefore, only charging box suppliers' value propositions and business models are included (not EV suppliers). Based on market research, the charging-box suppliers' value propositions and business models for EV home charging in Denmark are shown in Table 12. Meanwhile, four business models are founded for EV home charging in Denmark:

\section{One-time purchase}

EV owners purchase charging boxes from EV suppliers or retail stores; EV owners pay electricity suppliers the electricity bill including electricity consumed by EV charging.

In this business model, charging boxes are provided by EV suppliers such as Tesla that can ensure charging boxes follow the specific EV standards. Tesla, for instance, uses a different charger compared to other EVs. However, charging boxes are not usually included in EV purchases. In Denmark, the electricity consumed for EV charging is usually paid as part of the electricity bill to electricity suppliers. A similar business model applies to buy charging-boxes from retail stores like Power, Bilka, Thansen, etc.

\section{Renting}

EV owners rent charging boxes from charging box suppliers; EV owners pay electricity suppliers the electricity bill including electricity consumed by EV charging; EV owners receive a reimbursement from charging box suppliers.

To compete with the business model of one-time purchase, charging box suppliers provide a reimbursement of $1.1 \mathrm{DKK} / \mathrm{kWh}$ to EV owners. This reimbursement is what charging-box suppliers receive from the government. Due to Danish regulation,

Table 10 The related actors and their roles in the Danish EV home charging business ecosystem

\begin{tabular}{ll}
\hline From actor/object & Role \\
\hline TSO & Transmission system operator \\
DSO & DataHub responsible \\
& Distribution system operator \\
Electricity supplier & Data collector \\
Domestic consumer & Electricity retailer \\
& Electricity consumer \\
Charging-box supplier & Electric vehicle user \\
DataHub & Meter for consumption \\
Electric vehicle & Service provider \\
Charging-box & DataHub \\
& Electric vehicle \\
\hline
\end{tabular}

The excluded actors are: 'BRP for consumption; SKAT, the tax collector

The excluded roles are: 'Market operator' role of actor 'TSO'; 'Tax payment responsible' role of actor 'DSO 
Table 11 The list of EV suppliers and charging-box suppliers in Denmark

\begin{tabular}{ll}
\hline List of EV suppliers in Denmark & List of charging-box suppliers in Denmark \\
\hline Audi & Clever \\
BMW & E.ON \\
Hyundai & EVSE.dk \\
Jaguar & Sperto \\
Kia & FDM \\
Mercedes & EV suppliers (e.g. Tesla, Mercedes etc.) \\
Nissan & The charger APS, ladertilelbil.dk, and Power \\
Porsche & Thansen \\
Renault & Proshop \\
Seat & Bilka and Føtex \\
Smart & Schneider Electric \\
Tesla & \\
Volkswagen & \\
\hline
\end{tabular}

electricity used for specific business processes (EV charging is included) can receive a reimbursement of $1.1 \mathrm{DKK} / \mathrm{kWh}$ until 2021 (skat.dk 2020). Charging box suppliers own and maintain charging boxes, claim EV charging via them is a 'business process', therefore, can receive this reimbursement.

\section{Subscription}

EV owners pay a subscription to charging box suppliers for renting charging boxes at home, limited or unlimited EV charging at all charging boxes and stations owned by the charging-box suppliers; EV owners pay electricity suppliers the electricity bill including electricity consumed by EV charging; EV owners receive a refund with a fixed rate from charging-box suppliers.

In this business model, some charging-box suppliers have a capacity limitation (the amount of electricity that can be used for charging) but some have not. At home, charging boxes are installed behind the meter points operated by DSOs, therefore, EV owners have to pay the electricity suppliers the electricity bill including the normal household electricity consumption and the EV charging consumption. To avoid EV owners paying twice for EV charging, EV owners receive a fixed refund per $\mathrm{kWh}$ (for the electricity consumed by EV charging) from the charging box suppliers.

\section{V2G}

EV owners can participate in frequency reserves via a V2G platform.

This business model has been demonstrated in a pilot study in Denmark. A company called Nuvve offers charging boxes and a V2G platform, and has utilized V2G to participate in the frequency market. Their concept has been successfully tested with some EVs in the Parker project (Andersen et al. 2019). However, only some EVs are ready for V2G (e.g., Nissan LEAF (2014MY and newer), Nissan e-NV200, Mitsubishi iMieV, Mitsubishi Outlander PHEV) (Nuvve 2020). The V2G platform acts as an aggregator that can trade in the frequency market through a BRP (Andersen et al. 2019). 


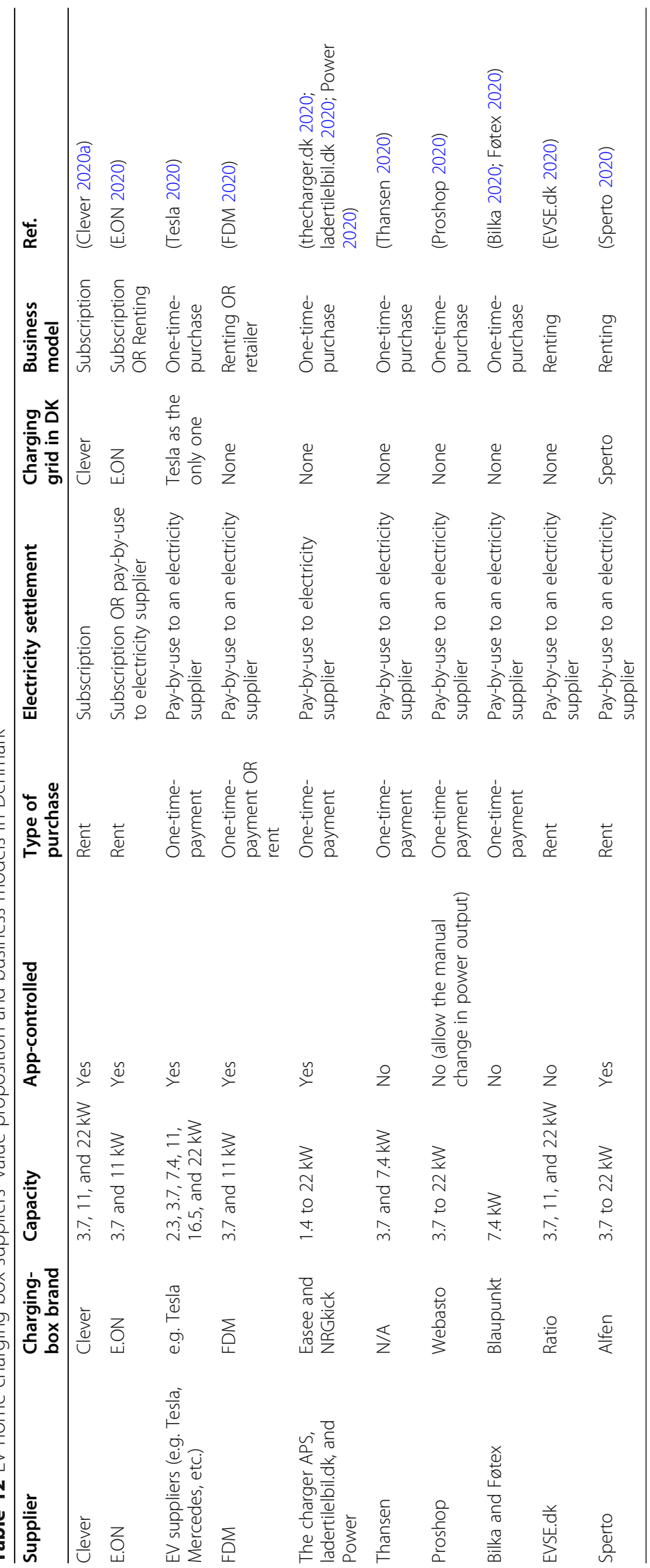




\section{Stage 4- Identification of interaction between actors}

Based on the references found in market research analysis, the interactions between actors and objects in the Danish EV home charging minimum viable business ecosystem are shown in Table 13.

\section{Stage 5- Verification of business ecosystem architecture design Design of minimum viable ecosystem, ecosystem roadmap, and transition stages}

Although four business models for EV home charging are found, the scenario of participation in frequency reserves is not the preliminary focus in this case study, and it can be considered as an expanded ecosystem. Among the other three business models, the business model - subscription is the most popular one in Denmark, and it will continuously be the most popular one in near future. Therefore, the minimum viable ecosystem is designed based on this business model.

\section{Completeness checking of value flows and interactions}

Based on Table 13, the EV home charging ecosystem mapping is shown in Fig. 3. This ecosystem map is created with a web-based tool-Ecosystem Map Generator (https:// ecosystemmapgenerator.sdu.dk/). The completeness of the four value flows and the intangible value interactions are checked by visualizing the individual flows and intangible value interactions as shown in Figs. 4, 5, 6, 7 and 8.

- The goods flow (shown in Fig. 4) includes EV charging electricity supply flow (Start point: distribution system; Endpoints: EV) and electricity supply flow (Start point: distribution system; Endpoints: electricity consumer).

- The monetary flow (shown in Fig. 5) includes EV charging monetary flow (Start point: EV owner and service provider (due to the specific case of reimbursement); Endpoint: service provider) and electricity monetary flow (Start point: electricity consumer; Endpoint: TSO and DSO).

- The data flow (shown in Fig. 6) includes EV charging data flow (Start points: charging point; Endpoint: service provider) and electricity consumption data flow (Start points: charging point and electricity consumer; Endpoint: electricity retailer).

- The information flow (shown in Fig. 7) includes EV charging information flow (Start point: EV owner; Endpoint: EV) and tariff information flow (Start point: TSO and DSO; Electricity consumer).

- The intangible interactions (shown in Fig. 8) include 6 intangible interactions (5 from an actor to an object, and 1 from an actor to another actor) shown in Tables 14 and 15 .

The results above confirm that there are start and end points for the four flows and the flows are continuous without any broken links. Meanwhile, each object has an intangible value interaction with an actor. Therefore, the designed ecosystem architecture can be verified.

\section{Discussions}

Ontology is a domain-specific, formal, explicit specification that supports the process in agreement with all parties (Ma et al. 2019). Especially, a business ecosystem involves 


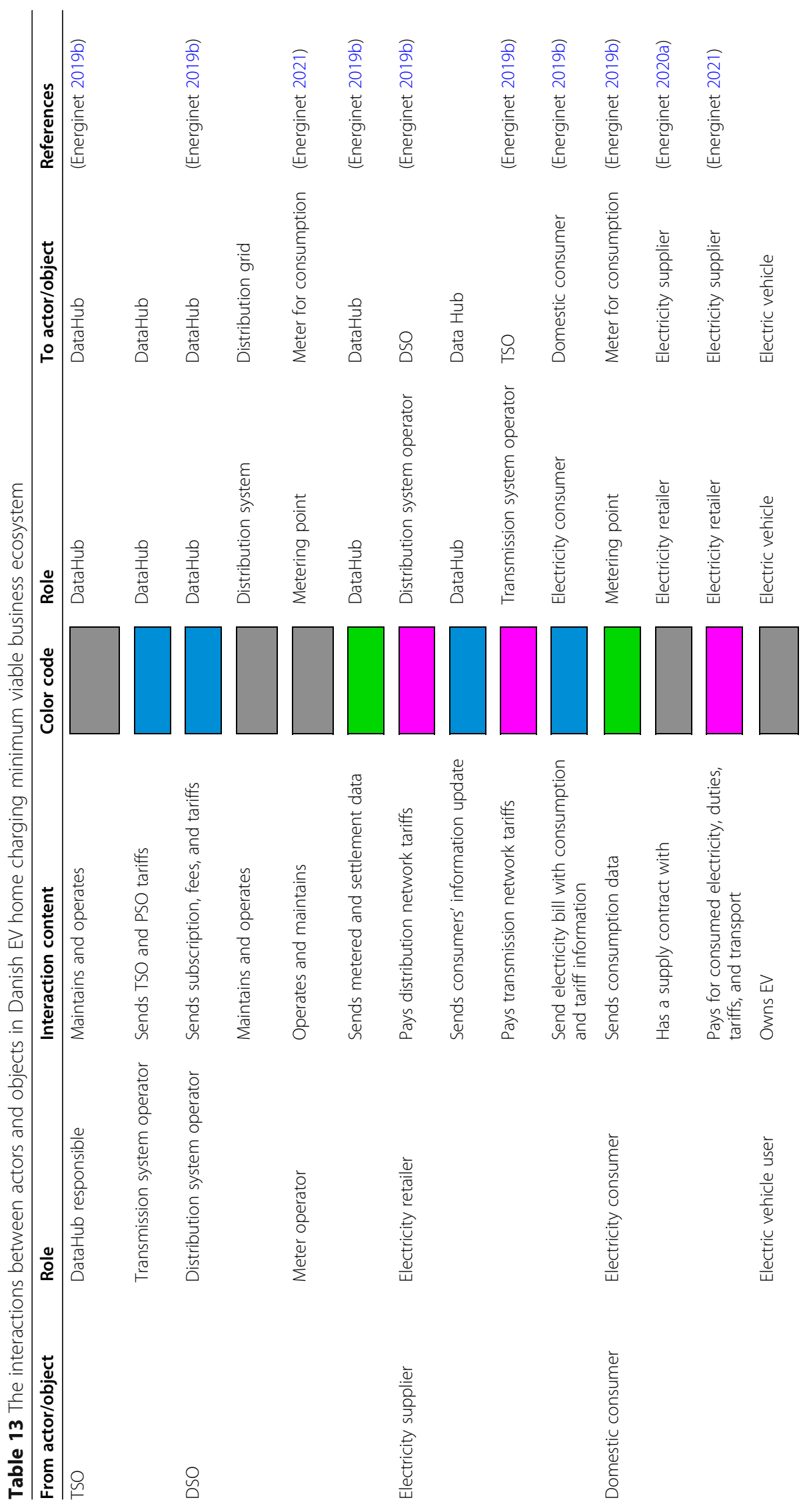




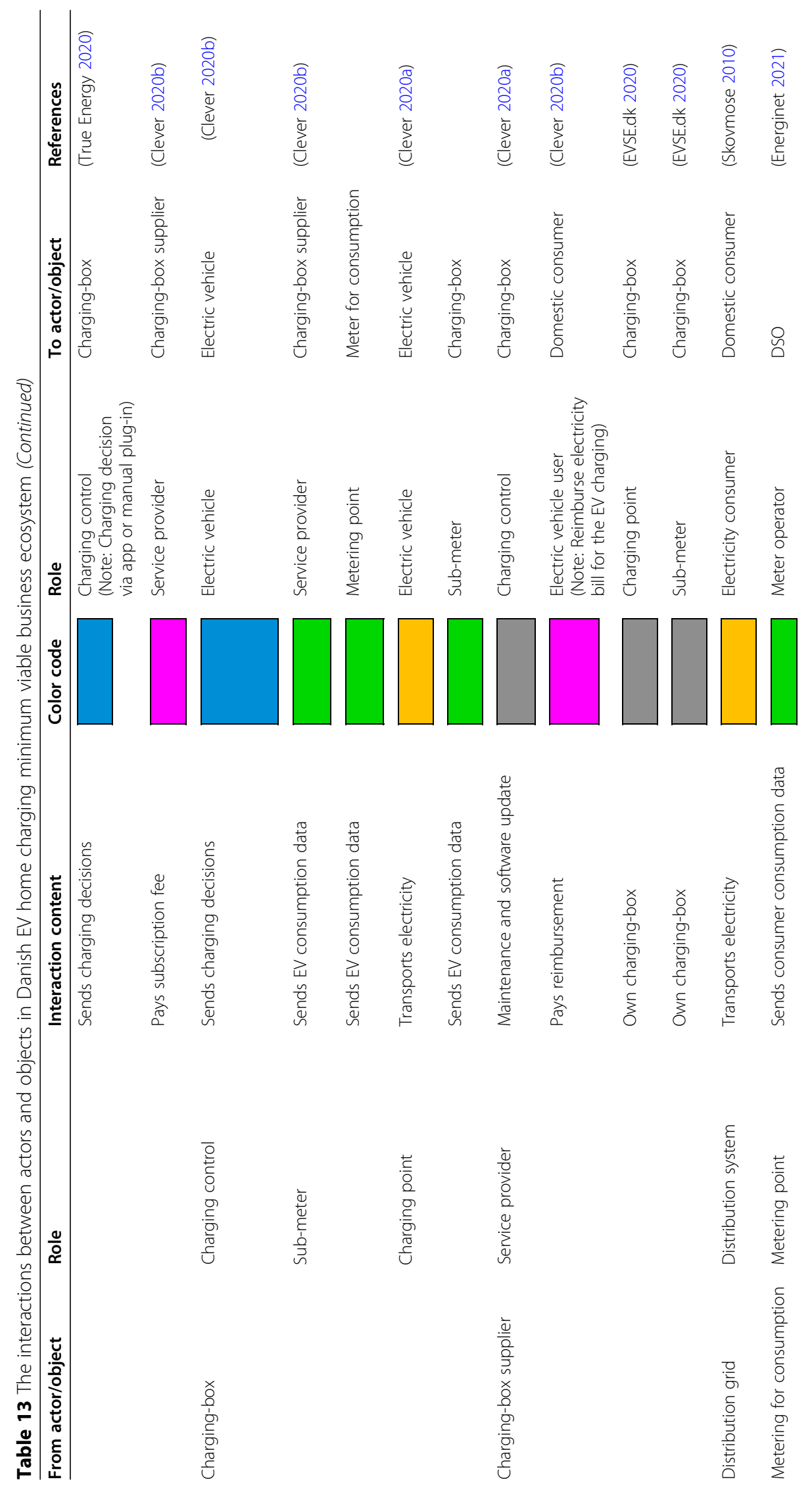




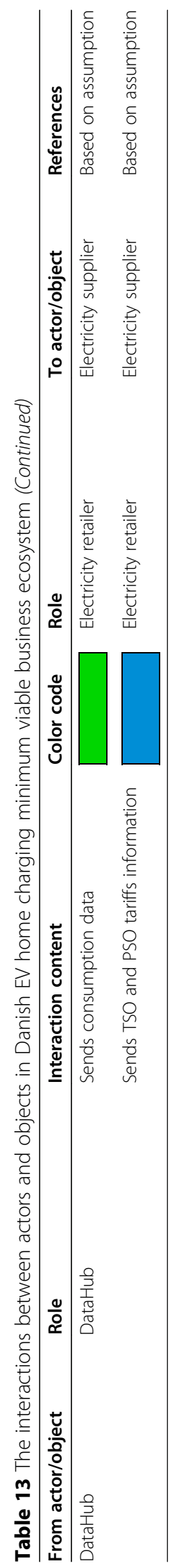




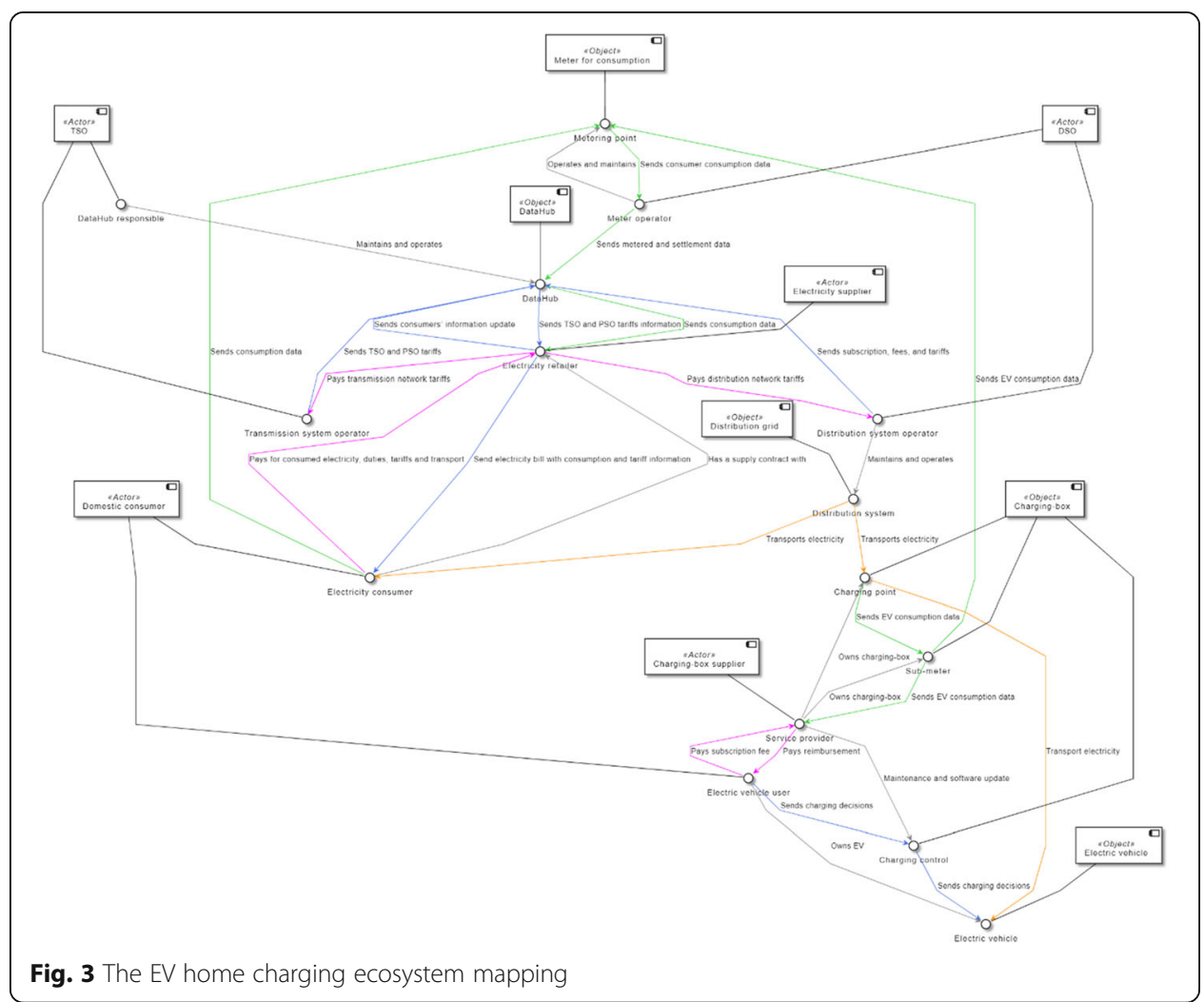

many actors and roles that require an explicit specification and process. Therefore, several definitions are clarified in the paper:

- Ecosystem architecture: illustrate the design and structure of a business ecosystem that actors create values (value proposition) and interact with others (business models) to complete four value flows within a defined ecosystem boundary.

- Minimum Viable Ecosystem: is a completed ecosystem with minimum elements (actors, roles, and interactions), but still can serve the identified ecosystem boundary.

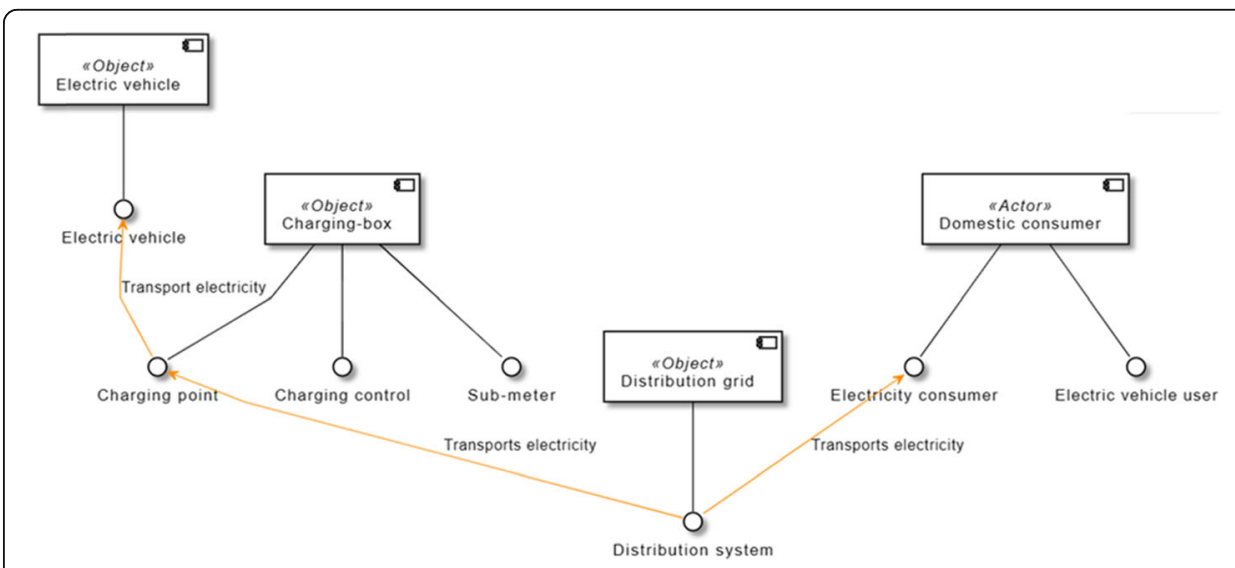

Fig. 4 The goods flow in the EV home charging ecosystem 


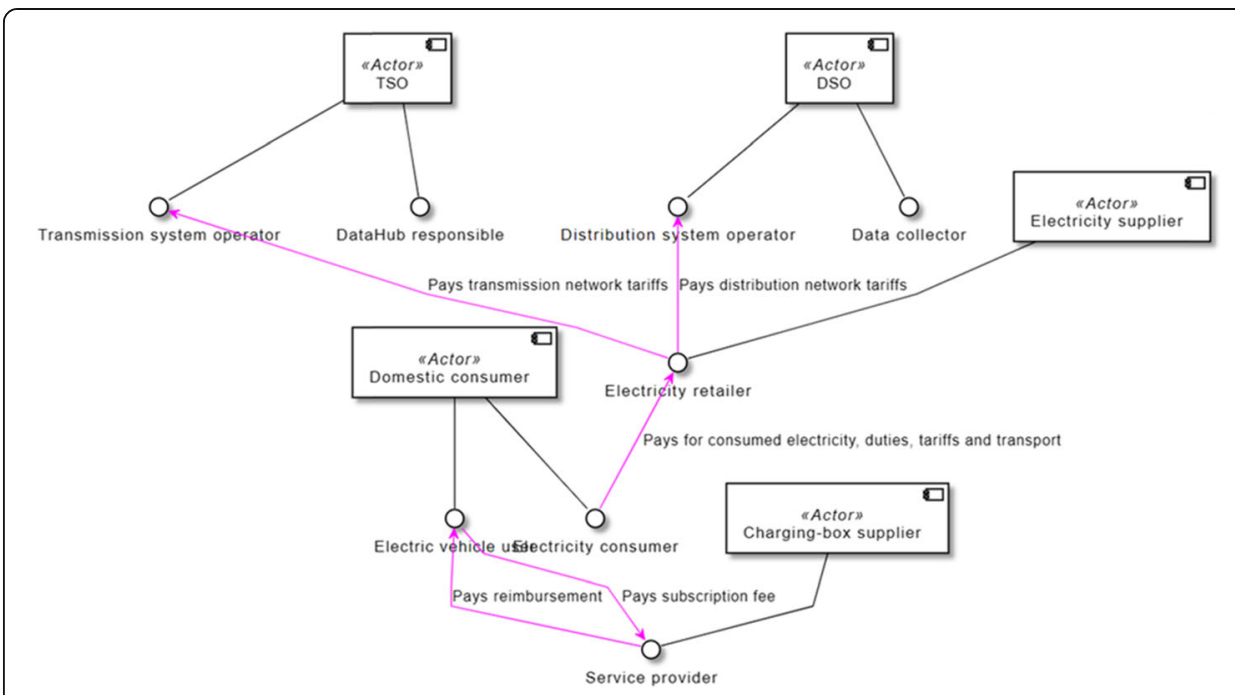

Fig. 5 The monetary flow in the EV home charging ecosystem

- Expanded/shifted ecosystem: is a completed and minimum ecosystem that expands/ shifts from the previous ecosystem (e.g., MVE) with added elements to service an expanded/shifted ecosystem boundary.

- Ecosystem roadmap: is a critical path with sequenced ecosystem transition stages for achieving the planned/future ecosystem.

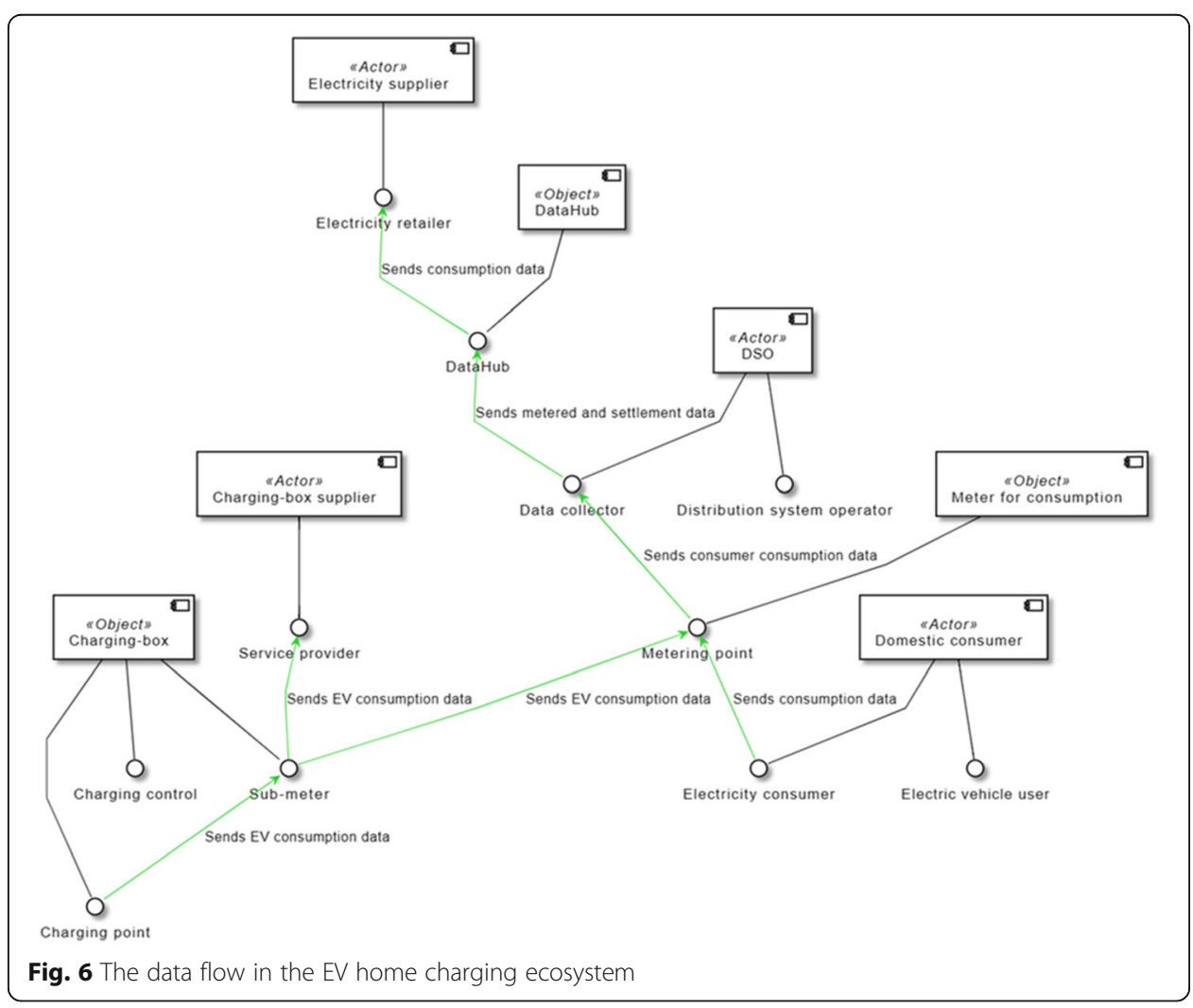



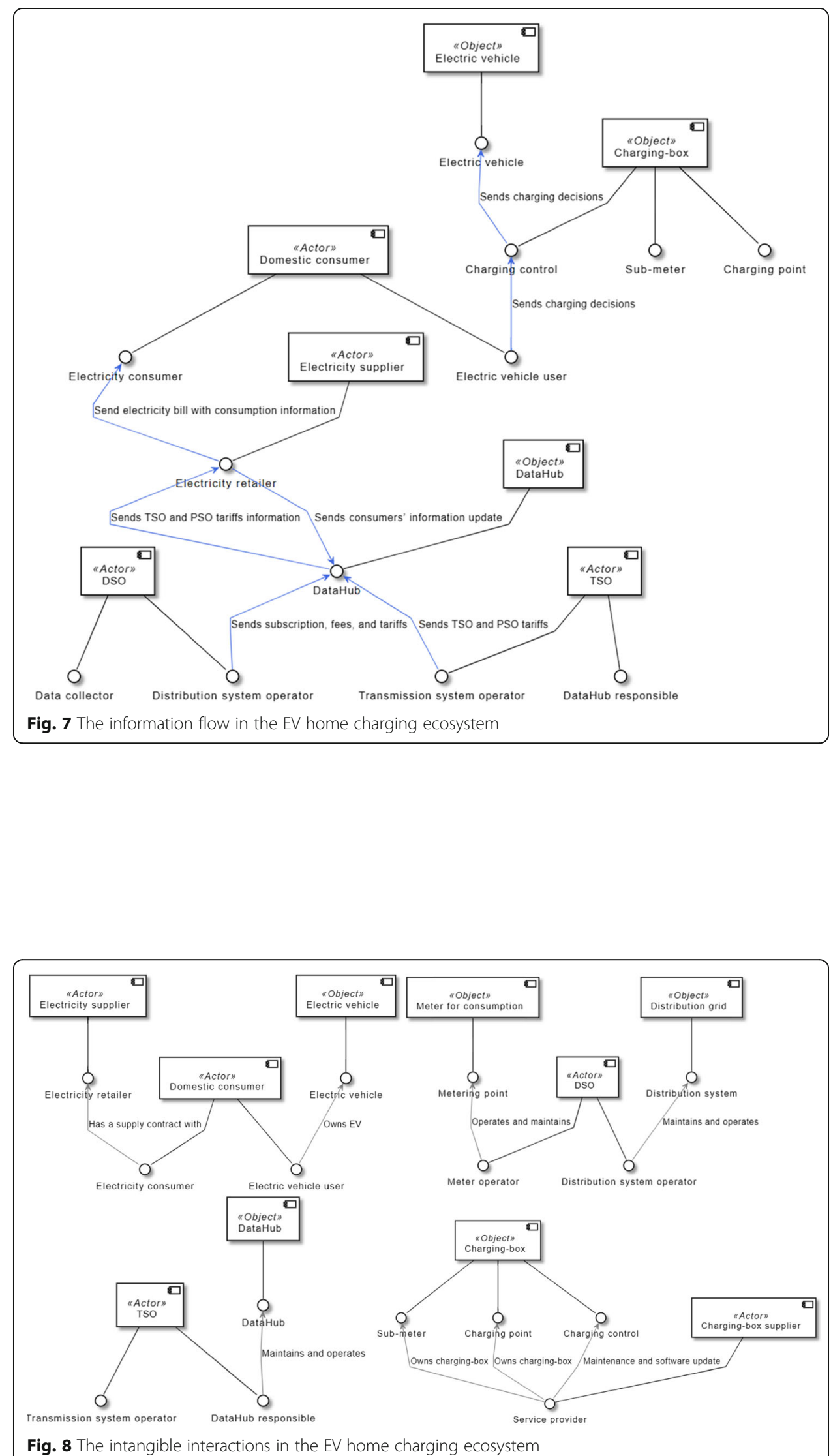

Fig. 8 The intangible interactions in the EV home charging ecosystem 
Table 14 Six intangible interactions in the EV home charging ecosystem

\begin{tabular}{ll}
\hline From Actor-Role & To Object/Actor-Role \\
\hline EV owner & EV \\
Electricity consumer & Electricity retailer \\
Meter operator & Metering point \\
DSO & Distribution system \\
DataHub responsible & DataHub \\
Service provider & Charging box \\
\hline
\end{tabular}

- Transition stage: One MVE or expanded/shifted ecosystem is designed at one transition stage. The sequence of the transition stages can be either horizontal (boundary scale) dependent on the boundary coverage or vertical (time scale) dependent on the realization terms (short, medium, and long terms).

- Ecosystem boundary: includes two dimensions of the targeted domain and cultural/ geographic boundary.

- Targeted domain: is defined by the primary supply chain, main business, and related markets. It aims to identify 'what' and 'who' of the business ecosystem.

- Cultural/geographic boundary: identifies 'where' and 'how' of the business ecosystem.

- Stakeholder: any individual, company, organization, agency, or institution who has an interest in or influence the business ecosystem

- Actor: type of stakeholders who directly participate in the ecosystem's value creation process

- Role: actor's responsibility in the business ecosystem

- Value flow: a specific type of value moves (via interaction) into one direction continuously

- Interaction: communication between two actors/objects for a type of value cocreation. The five values are:

- Value of goods: the basic products of an economic system that consist of tangible consumable items (products) and tasks performed by individuals (service).

- Monetary value: the amount of value an item or a service has in relation to if it is sold for cash to a buyer.

- Value of information: data that has been processed, organized, structured or presented to make it useful in a given context.

- Value of data: raw, unorganized measurements and facts that need to be processed to become useful.

- Intangible value: something that exists but cannot be exactly described, or given an exact value.

The developed business ecosystem architecture not only can illustrate involved actors, roles and interactions, but also the types and content of the interactions. In the proposed methodology, one interaction is related to two roles, not actors directly. It is because roles/responsibilities are usually defined by e.g., regulations, especially in the energy sector, and this way can clearly illustrate why there is a relationship between two actors; secondly, this way can make the business ecosystem architecture more 
Table 15 The five-stage business ecosystem architecture design approach with a detailed explanation

\begin{tabular}{|c|c|c|c|c|}
\hline $\begin{array}{l}\text { Stage of the } \\
\text { business } \\
\text { ecosystem } \\
\text { architecture } \\
\text { development }\end{array}$ & Purpose & Activities & Output & $\begin{array}{l}\text { Input/ } \\
\text { methods }\end{array}$ \\
\hline $\begin{array}{l}\text { Stage 1- } \\
\text { Boundary } \\
\text { identification of } \\
\text { a business } \\
\text { ecosystem }\end{array}$ & $\begin{array}{l}\text { Define and describe the } \\
\text { targeted business } \\
\text { ecosystem boundary } \\
\text { with two dimensions } \\
\text { (the targeted domain } \\
\text { and the cultural/ } \\
\text { geographic boundary) }\end{array}$ & $\begin{array}{l}\text { Investigate } \\
\text { 1) the primary and } \\
\text { secondary supply chain, } \\
\text { 2) main business, } \\
\text { 3) markets }\end{array}$ & $\begin{array}{l}\text { The targeted business } \\
\text { ecosystem boundary } \\
\text { is defined and } \\
\text { described with the } \\
\text { two dimensions; } \\
\text { The primary and } \\
\text { secondary supply } \\
\text { chain, main business, } \\
\text { and markets are } \\
\text { described }\end{array}$ & $\begin{array}{l}\text { Market } \\
\text { research }\end{array}$ \\
\hline $\begin{array}{l}\text { Stage 2- } \\
\text { Identification of } \\
\text { actors and their } \\
\text { roles in the } \\
\text { business } \\
\text { ecosystem }\end{array}$ & $\begin{array}{l}\text { Identify actors and their } \\
\text { roles }\end{array}$ & $\begin{array}{l}\text { - Identify roles according } \\
\text { to legal requirements } \\
\text { for primary and/or } \\
\text { secondary supply } \\
\text { chains and markets } \\
\text { - Identify actors and their } \\
\text { roles based on the } \\
\text { roles assigned to them }\end{array}$ & $\begin{array}{l}\text { Actors and their roles } \\
\text { are identified }\end{array}$ & $\begin{array}{l}\text { The output } \\
\text { from Stage } \\
1 ; \\
\text { Market } \\
\text { research }\end{array}$ \\
\hline $\begin{array}{l}\text { Stage 3- } \\
\text { Identification of } \\
\text { actors' value } \\
\text { propositions }\end{array}$ & $\begin{array}{l}\text { Identify value } \\
\text { propositions for each } \\
\text { role and identify the } \\
\text { potential interactions } \\
\text { between roles }\end{array}$ & $\begin{array}{l}\text { Identify value } \\
\text { propositions and related } \\
\text { business models for the } \\
\text { correlated roles }\end{array}$ & $\begin{array}{l}\text { Value propositions } \\
\text { and business models } \\
\text { for each correlated } \\
\text { role are identified and } \\
\text { described }\end{array}$ & $\begin{array}{l}\text { The output } \\
\text { from Stage } \\
2_{i} \\
\text { Market } \\
\text { research }\end{array}$ \\
\hline $\begin{array}{l}\text { Stage 4- } \\
\text { Identification of } \\
\text { interaction } \\
\text { between actors }\end{array}$ & $\begin{array}{l}\text { Identify the types and } \\
\text { content of the } \\
\text { interaction between } \\
\text { roles }\end{array}$ & $\begin{array}{l}\text { - Identify interaction } \\
\text { content between two } \\
\text { roles } \\
\text { - Identify the types } \\
\text { (among five types of } \\
\text { interaction) of } \\
\text { interaction between } \\
\text { two roles with } \\
\text { correlated colors }\end{array}$ & An interaction table & $\begin{array}{l}\text { The output } \\
\text { from Stage } \\
3 ; \\
\text { Market } \\
\text { research; } \\
\text { Assumptions }\end{array}$ \\
\hline $\begin{array}{l}\text { Stage 5- } \\
\text { Verification of } \\
\text { business } \\
\text { ecosystem } \\
\text { architecture } \\
\text { design }\end{array}$ & $\begin{array}{l}\text { Design minimum viable } \\
\text { ecosystem and } \\
\text { ecosystem roadmap } \\
\text { Visualize the developed } \\
\text { business ecosystem } \\
\text { architecture } \\
\text { Check completeness }\end{array}$ & $\begin{array}{l}\text { Identify the minimum } \\
\text { elements (actors, roles, } \\
\text { and their interaction) of } \\
\text { the targeted business } \\
\text { ecosystem; } \\
\text { Identify ecosystem } \\
\text { roadmap with the } \\
\text { expansion stages and } \\
\text { expanded ecosystem (if } \\
\text { necessary) } \\
\text { Convert the minimum } \\
\text { viable business } \\
\text { ecosystem architecture } \\
\text { (from the Interaction } \\
\text { table) to the business } \\
\text { ecosystem map } \\
\text { Check completeness of } \\
\text { individual value flows } \\
\text { and intangible value } \\
\text { interactions between } \\
\text { objects and actors }\end{array}$ & $\begin{array}{l}\text { An MVE table and list } \\
\text { of actors, roles and } \\
\text { interactions } \\
\text { A business ecosystem } \\
\text { map diagram } \\
\text { Five figures for the } \\
\text { four value flows and } \\
\text { intangible value } \\
\text { interactions }\end{array}$ & $\begin{array}{l}\text { The output } \\
\text { from Stage } 3 \\
\text { and Stage } 4 \\
\text { (business } \\
\text { model); } \\
\text { Research } \\
\text { aims/focuses }\end{array}$ \\
\hline
\end{tabular}

flexible. When actors or roles change in a business ecosystem, interactions can be moved or changed without influence other roles for the assigned actors and other actors. Meanwhile, one interaction only has one direction (from a role to another role), because value flows have directions, and the actor who supplies goods to consumers is 
not always the actor who gets the payment directly from consumers. It is common in the supply chain domain, but not in the business ecosystem domain.

The Danish electricity distribution and transmission networks are used as examples to explain the methodology, the case study of EV home charging follows the five steps and is an expanded ecosystem from the distribution network ecosystem. It demonstrates that the architecture design for the expanded/shifted ecosystems can be much faster and easier once the MVE is developed.

An ecosystem map generator is used in the case study for visualizing the developed business ecosystem architecture and investigating the four flows and intangible value interactions. Since there are two supply chains (electricity supply and EV charging) in the EV home charging ecosystem, each type of value flow includes two sub-flows that represent the two supply chains. It also supports the verification of the designed ecosystem architecture.

Compared to TOGAF (The Open Group Architecture Framework) (The Open Group 2020) that focuses on the focal organization perspective and has no definition or description of value types between businesses or enterprises, the proposed methodology is a systematic approach and the designed ecosystem architectures can represent the physical systems and businesses, and their interactions from an ecosystem perspective.

Two model frameworks in the smart grid domain that are popularly used in Europe are the harmonized electricity market role model (ENTSO-E 2018) and the SGAM (Smart Grids Architecture Model) framework (Smart Grid Coordination Group 2012). The harmonized electricity market role model mainly focuses on the market and IT perspectives to enable the common understanding among market participants from different countries via a common IT terminology for information exchange. The SGAM framework presents the design of the smart grid from an architectural viewpoint. Although these two model frameworks include the business aspect, the main focus is still the technical requirements and only in the smart grid domain. Comparatively, the proposed methodology provides an ontology that links business, system, modeling and simulation.

\section{Conclusions}

This paper introduces a five-stage methodology for design the business ecosystem architecture with a detailed explanation and a case study of EV home charging. The case study demonstrates that the proposed methodology is a systematic approach and can be easily applied to any ecosystem architecture design with the five stages. Especially with the three State-of-the-Art techniques (market research, literature review, and patent search), the designed ecosystem architecture can represent the physical system and business.

The introduced five-stage methodology (shown in Table 15) can facilitate the design of a business ecosystem architecture, and identify the elements (actors, roles, and interaction) in the targeted business ecosystem. The developed business ecosystem architecture is the foundation for Part II Factor analysis (in Table 1) that investigates influential factors and their impact on elements and potential changes in a business ecosystem. The result will also be the input to Part III-Ecosystem simulation and reconfiguration (in Table 1). There are several types of modeling, e.g. visual, mathematical, and computational modeling. Computational agent-based modeling (e.g., 
(Christensen et al. 2019) is recommended to investigate the dynamics and reconfiguration of a business ecosystem.

\section{Contributions}

As stated in (Ma 2019), there is little literature on the modeling aspect of the business ecosystem. With clear definitions, the proposed methodology for the ecosystem architecture design provides a visualized, clear structure of behaviors and specifications for a given business ecosystem. Compared to classic system architecture development approaches that mainly aim to provide a guideline, e.g. TOGAF (The Open Group Architecture Framework) (The Open Group 2020) and DoDAF (the Department of Defence Architecture Framework) (U.S. Department of Defense 2010), the proposed methodology systematically introduces how to conduct the business ecosystem architecture design step by step.

The proposed methodology not only decodes the process to configure roles and actors, but also interactions in a business ecosystem. No literature has explicitly introduced how actors interact in a business ecosystem, although some literature has introduced value flows in a business ecosystem. Five types of interactions in a business ecosystem are defined in this paper to illustrate the value and the value direction among actors. Interactions are assigned to roles, not actors to represent regulatory responsibilities and ecosystem reconfiguration flexibility.

As discussed in (Ma 2019), a domain ontology is important that defines various kinds of objects, properties, and relations. Little literature has mentioned ontology design for business ecosystem modeling, although ontologies are known to be important in intelligent system development for modeling interoperability, composition, and information exchange at the semantic level. Therefore, the proposed ontology for business ecosystem modeling fills this gap.

This methodology is also highly relevant for practitioners and decision-makers, especially for reflecting on the adoption and implementation of new technologies.

\section{Future works}

This paper mainly introduces the methodology for the business ecosystem architecture design, and the next step is to introduce Part III- Ecosystem simulation and reconfiguration. A multi-agent based simulation will be developed and a methodology for transforming the designed business ecosystem architecture to a business ecosystem digital twin will be introduced. The case study of the EV home charging ecosystem will be implemented to investigate the impacts of EV home charging on the distribution grids in Denmark.

The web-based tool-Ecosystem Map Generator (https://ecosystemmapgenerator.sdu. $\mathrm{dk} /$ ) can facilitate the majority of the stages in the proposed methodology but except Stage 1. Meanwhile, the visualization of the ecosystem architecture can not illustrate the supply chains. Therefore, it is necessary to improve some functionalities in the tool.

\section{Appendix}

\section{Electricity retailers in Denmark}

In the Danish electricity retail market, consumers are able to freely choose electricity retailers in Denmark. So far, there are around 59 electricity retailers in Denmark (EL 
PRIS.DK 2021) (shown in Table 16 below), and there is no significant price difference among the existing electricity retailers.

\section{DSOs in Denmark}

The distribution system operator owns the network between the transmission grid and the consumer. A DSO has a monopoly on transporting electricity in its geographically demarcated grid area. So far, there are around 48 DSOs in Denmark (Dansk Energi 2021) (shown in Table 17 below).

\section{Balance Responsible Parties (BRPs) in Denmark}

Balance responsible parties buy and sell electricity at Nord Pool Sport on behalf of the electricity suppliers and plant owners. In Denmark, there are 46 approved balance responsible parties (Energinet 2009) (shown in Table 18).

Table 16 Electricity Retailers in Denmark

\begin{tabular}{lll}
\hline AURA El-handel A / S & Gul Strøm A / S & SE \\
Barry & Hjerting Elhandel A / S & SEF Energi A / S \\
Blue Energy A / S & Hudya & SK Energisalg A / S \\
Bornholms Energi \& Forsyning & Jysk Energi & Streamlined \\
DCC E & Kibæk Elhandel A / S & Struer Energi \\
Elektron A / S & Langelands Elforsyning A / S & Sunds Elhandel A / S \\
Energi Fyn Handel A / S & MES Elhandel A / S & Tarm Elhandel A / S \\
Energi Hurup Elhandel A / S & Midtjysk Elhandel & Thy-Mors Energi \\
Energi lkast & Modstrøm Danmark A / S & True Energy \\
Energi Viborg Strøm & Nef Strøm A / S & Welcome A / S \\
Energi Danmark & NettoPower Aps & Vestforsyning \\
Eniig & NGF Nature Energy & Verdo Go Green A / S \\
E. ON & Norsk Elkraft Danmark A / S & Videbæk Elhandel A / S \\
EWII Energi & Norström A / S & Vindstød A / S \\
Forskel & NRGi Elsalg A / S & VTV Elhandel A / S \\
Forsyning Helsingør & OK & Ørsted \\
Frederikshavn Elhandel A / S & RAH Elhandel A / S & Aal Elhandel A / S \\
Gasel.dk & Samstrøm A / S & Aars Elforsyning A / S \\
GEV Elhandel A / S & Scanenergi A / S & \\
GNPower & SEAS-NVE Strømmen A / S & \\
\hline
\end{tabular}


Table 17 Distribution system operators in Denmark

\begin{tabular}{llll}
\hline Dinel & Nakskov Elnet & Vores Elnet A/S & Nibe Elforsyning \\
El-net Øst A/S & NKE Elnet & Net8800 A/S & NOE Net \\
N1 A/S & Nord Energi Net & Elektrus A/S & Radius Elnet \\
Elinord A/S & RAH Net & Grindsted El-net A/S & Ravdex \\
VEKSEL A/S & Struer Forsyning Elnet A/S & Konstant Net A/S & Sunds Elforsyning \\
Cerius A/S & Tarm Elværk Net A/S & FLOW Net A/S & Thy-Mors Energi Elnet \\
Elnet Zealand A/S & TRE-FOR Elnet & Evonet A/S & Verdo Hillerød El-net A/S \\
Hammel Elforsyning Net & Verdo Randers El-net A/S & Hirtshals El-netselskab & Vestjyske Net 60 kV \\
Hjerting Transformer-forening & Videbæk Elnet & Hurup Elværk & Vildbjerg Elværk \\
Ikast El-net A/S & Vordingborg Elnet & Kibæk Elværk & Aal Elnet \\
Kjellerup Elnet & Års-Hornum Net & Kongerslev Elnet & Syd Energi \\
Læsø Elnet & Nyfors Net & Midtfyns Elforsyning & Energi-Midt \\
\hline
\end{tabular}


Table 18 The Balance Responsible Parties in Denmark

Actor

Production

Consumption

Trade

Alpiq AG

Axpo Nordic AG

$x$

Axpo Trading AG

Danske Commodities A/S

Edf Trading Limited

Ekologicke Zdroje

Electrade Spa

Enel Trade Spa.

Energi Danmark A/S

Energinet.dk

Energya Vm Gestión De Energía Slu

Entelios Aps

E.On Sverige Ab

European Energy Exchange Ag

Ewii Energi A/S

Global Energy Division,

Hofor Energiproduktion A/S

In Commodities A/S

Kinect Energy Denmark A/S

Los A/S

Markedskraft Danmark

Mercuria Energy Trading Sa

Mft Energy A/S

Modity Energy Trading Ab

Modity Energy Trading Ab

Modstrøm Danmark A/S

Neas Energy A/S

Nord Pool Spot As

Norsk Elkraft Danmark A/S

Optimax Energy Gmbh

Powermart Aps

RWE Supply \& Trading Gmbh

Scanenergi A/S

Shell Energy Europe Limited

Statkraft Markets Gmbh

Stadtwerke Flensburg Gmbh

Statkraft Energi As

Total Gas And Power Ltd.

Trailstone Gmbh

Uniper Global Commodities Se

Vattenfall $A / S$

Vattenfall Energy Trading Gmbh

Vitol S.A.

Ørsted Bioenergy \& Thermal Power A/S

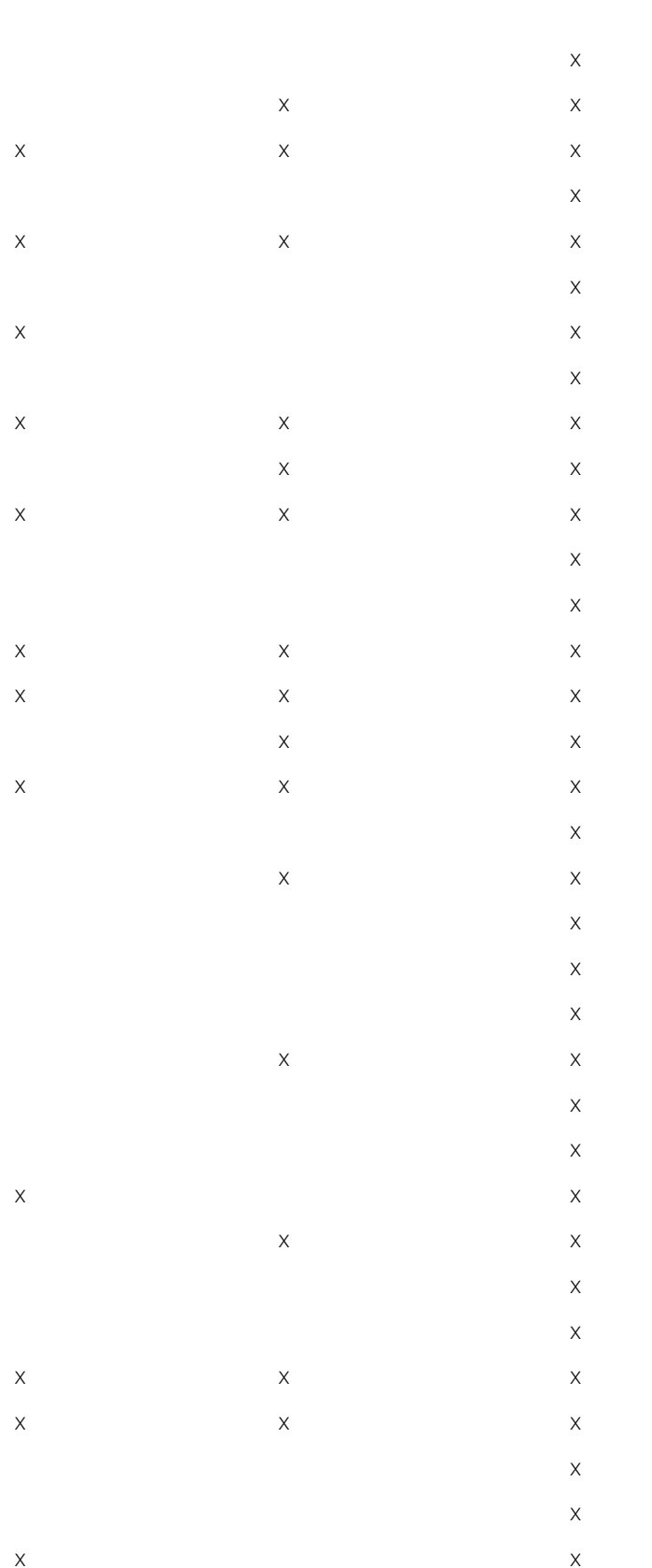


Table 18 The Balance Responsible Parties in Denmark (Continued)

\begin{tabular}{llll}
\hline Actor & Production & Consumption & Trade \\
\hline Ørsted Salg \& Service A/S & $\times$ & $\times$ & $\times$ \\
$\varnothing$ stkraft Produktion A/S & $\times$ & & $x$ \\
\hline
\end{tabular}

\section{Abbreviations}

EU: European Union; DK: Denmark; TSO: Transmission System Operator; DSOs: Distribution System Operators; SKAT: Central Danish tax administration; MVE: Minimum Viable Ecosystem; BRP: Balance responsible party; ACM: Association for Computing Machinery; EV: Electric Vehicle; DKK: Danish Kroner; V2G: Vehicle-to-Grid; TOGAF: The Open Group Architecture Framework; DoDAF: The Department of Defence Architecture Framework)

\section{Acknowledgments}

This study was conducted as part of the Flexible Energy Denmark project (https://www.flexibleenergydenmark.dk/).

\section{Authors' contributions}

ZM carried out the first draft of the paper, KC contributed to the case study section, and BNJ contributed to the ideas and participated in the paper revision. All authors read and approved the final manuscript.

\section{Funding}

This study was conducted as part of the Flexible Energy Denmark project (https://www.flexibleenergydenmark.dk/).

\section{Availability of data and materials}

Data sharing not applicable to this article as no datasets were generated or analyzed during the current study.

\section{Declarations}

Ethics approval

Not applicable.

\section{Consent for publication}

Not applicable.

\section{Competing interests}

The authors declare that they have no competing interests.

\section{Author details}

${ }^{1}$ SDU Health Informatics and Technology, The Maersk Mc-Kinney Moller Institute, University of Southern Denmark, Odense, Denmark. ${ }^{2}$ SDU Center for Energy Informatics, The Maersk Mc-Kinney Moller Institute, University of Southern Denmark, Odense, Denmark.

Received: 22 February 2021 Accepted: 17 May 2021

Published online: 24 June 2021

\section{References}

Adner R. The wide lens: a new strategy for innovation: 2012. Penguin.com

Adner R (2016) Ecosystem as structure: an actionable construct for strategy. J Manag 43(1):39-58

Andersen PB, Toghroljerdi SH, Sørensen TM, Christensen BE, JCML H, Zecchino A (2019) The parker project - final report

Basole RC, Russell MG, Huhtamäki J, Rubens N, Still K, Park H (2015) Understanding business ecosystem dynamics: a datadriven approach. ACM Trans Manage Inf Syst 6(2):Article 6

Battistella C, Colucci K, De Toni AF, Nonino F (2013) Methodology of business ecosystems network analysis: a case study in Telecom Italia Future Centre. Technol Forecast Soc Chang 80(6):1194-1210. https://doi.org/10.1016/j.techfore.2012.11.002

Bilka. Blaupunkt Ladeboks til elbiler AWB1P32AT2NC 2020 [Available from: https:/www.bilka.dk/elektronik/batterier/bla upunkt-ladeboks-til-elbiler-awb1 p32at2nc/p/100491230?=https:/www.bilka.dk/elektronik/batterier/blaupunkt-ladeboks-tilelbiler-awb1p32at2nc/p/100491230?]

bilmagasinet.dk. Oversigt over elbiler på det danske marked i 20192019 [Available from: https://bilmagasinet.dk/guides/ elbiler-paa-det-danske-marked]

Bousquet F, Le Page C (2004) Multi-agent simulations and ecosystem management: a review. Ecol Model 176(3):313-332. https://doi.org/10.1016/j.ecolmodel.2004.01.011

Christensen K, Ma Z, Værbak M, Demazeau Y, Jørgensen BN (2019) Agent-based decision making for adoption of smart energy solutions. In: IV International Congress of Research in Sciences and Humanities Science and Humanities International Research Conference (SHIRCON 2019). IEEE, Lima

Clever. Let opladning til din elbil 2020a [Available from: https://clever.dk/produkter/]

Clever. Hvordan fungerer strømafregningen for ladeboksen? 2020b [Available from: https://clever.dk/opladning-hjemme-ogpaa-farten/tilbagebetaling/]

Dansk Energi. Find elnetselskab 2021 [Available from: https://www.danskenergi.dk/vejledning/nettilslutning/find-netselskab]

E.ON. Strøm til din elbil 2020 [Available from: https://www.eon.dk/privat/strom-til-din-elbil.html]

Ea Energy Analyses. The Nordic electricity market and how it can be improved. 2012

EL PRIS.DK. Elleverandører og mæglere i Danmark 2021 [Available from: https:/elpris.dk/\#/article/liste_elhandlere_og_elmaeglere] 
Energinet. Udvikling af rammer for regulerkraft 2009 [Available from: http://www.ft.dk/samling/20091/almdel/epu/bilag/336/ 874447.pdf]

Energinet. Regulation C1 - Terms of balance responsibility. 2011

Energinet. Forretningsprocesser for det danske elmarked. 2018

Energinet. Introduktion til elmarkedet - Kort introduktion til engros- og detailmarkedet. 2019a

Energinet. The Danish Electricity Retail Market - Introduction to Datahub and the Danish supplier-centric model. 2019b

Energinet. Forskrift C2 - Balancemarked og balanceafregning. 2019c

Energinet. Roller og opgaver på elmarkedet 2020a [Available from: https://energinet.dk/El/Elmarkedet/Roller-paa-elmarkedet]

Energinet. What is the purpose of Datahub 2020b [Available from: https://en.energinet.dk/Electricity/DataHub\#Documents]

Energinet. Forskrift D1 - Afregningsmåling. 2020c

Energinet. Tariffer og gebyrer 2020d [Available from: https://energinet.dk/El/Elmarkedet/Tariffer]

Energinet. Roles \& Responsibilities 2021 [Available from: https://en.energinet.dk/Electricity/New-player/Roles-andresponsibilities]

ENTSO-E. The harmonised electricity market role model. 2018

European Comission. Energy and environment - Overview 2012 [Available from: https://ec.europa.eu/competition/sectors/ energy/overview_en.html]

EVSE.dk. Lej en kvalitets ladeboks på abonnement, og få afgiften tilbage 2020 [Available from: https://www.evse.dk/la debokse-med-abonnement/]

FDM. FDM Ladeboks til elbil og plugin hybrid 2020 [Available from: https:/fdm.dk/vi-tilbyder/fdm-ladeboks-til-elbil-plugin-hybrid]

Føtex. Blaupunkt Ladeboks til elbiler AWB1P32AT2NC 2020 [Available from: https://www.foetex.dk/elektronik/batterier/bla upunkt-ladeboks-til-elbiler-awb1p32at2nc/p/100491230]

lansiti M, Levien R (2004) Strategy as ecology. Harv Bus Rev 82(3):68-78

lyawa GE, Herselman M, Botha A (2016) Digital health innovation ecosystems: from systematic literature review to conceptual framework. Proc Comput Sci 100:244-252. https://doi.org/10.1016/j.procs.2016.09.149

Jensen LO. Det Danske Elmarked 2010 [Available from: https://www.experimentarium.dk/klima/det-danske-elmarked/]

ladertilelbil.dk. Hvad du bør tænke på, før du køber en lader til elbil 2020 [Available from: https://ladertilelbil.dk/]

Laursen T. Elbiler arbejder for elnettet, når de holder stille: Energinet.dk; 2017 [Available from: https://energinet.dk/Om-os/ Historier-fra-Synergi/Elbiler-arbejder-for-elnettet-nar-de-holder-stille]

Levien R (2004) The keystone advantage: what the new dynamics of business ecosystems mean for strategy, innovation, and sustainability. Harvard business school press, Cambridge

Ma Z (2019) Business ecosystem modeling - the hybrid of system modeling and ecological modeling: an application of the smart grid. Energy Inf 2(1). https://doi.org/10.1186/s42162-019-0100-4

Ma Z, Asmussen A, Jørgensen B (2018) Industrial consumers' smart grid adoption: influential factors and participation phases. Energies. 11(1):182. https://doi.org/10.3390/en11010182

Ma Z, Asmussen A, Jørgensen BN (2015) Industrial consumers' acceptance to the smart grid solutions: case studies from Denmark. Smart Grid Technologies - Asia (ISGT ASIA). In: 2015 IEEE Innovative

Ma Z, Billanes JD, Jørgensen BN (2017b) A business ecosystem driven market analysis: the bright green building market potential. In: The 1st Annual International Conference of the IEEE Technology and Engineering Management Society. IEEE, Santa Clara

Ma Z, Billanes JD, Kjærgaard MB, Jørgensen BN (2017a) Energy flexibility in retail buildings: from a business ecosystem perspective. In: 2017 14th International Conference on the European Energy Market (EEM). IEEE, Dresden

Ma Z, Knotzer A, Billanes JD, Jørgensen BN (2020) A literature review of energy flexibility in district heating with a survey of the stakeholders' participation. Renew Sust Energ Rev 123:109750. https://doi.org/10.1016/j.rser.2020.109750

Ma Z, Prljaca Z, Jørgensen BN (2016) The international electricity market infrastructure-insight from the nordic electricity market. In: 2016 13th International Conference on the European Energy Market (EEM), IEEE, Porto, Portugal, pp. 1-5. https://doi.org/10.1109/EEM.2016.7521314

Ma Z, Schultz MJ, Christensen K, Værbak M, Demazeau Y, Jørgensen BN (2019) The application of ontologies in multi-agent systems in the energy sector: a scoping review. Energies. 12(16):3200. https://doi.org/10.3390/en12163200

Manning B, Runge B, Thorne C, Moore G (2002) Demand driven: 6 steps to building an ecosystem of demand for your business. McGraw-Hill Companies, New York

Marín CA, Stalker I, Mehandjiev N (2007) Business ecosystem modelling: combining natural ecosystems and multi-agent systems. cooperative information agents XI. Springer Berlin Heidelberg, Berlin, Heidelberg

Mlecnik E, Parker J, Ma Z, Corchero C, Knotzer A, Pernetti R (2019) Policy challenges for the development of energy flexibility services. Energy Policy 111147. https://doi.org/10.1016/j.enpol.2019.111147

Moore JF (1996) The death of competition: leadership and strategy in the age of business ecosystems. Harper Paperbacks, New York, U.S. pp 297

Nuvve. Danmark 2020 [Available from: https://nuvve.com/denmark]

Papert M, Pflaum A (2017) Development of an ecosystem model for the realization of internet of things (loT) services in supply chain management. Electron Mark 27(2):175-189. https://doi.org/10.1007/s12525-017-0251-8

Power. EASEE home opladningsstation sort 2020 [Available from: https://www.power.dk/hus-og-fritid/elbillader/ladestationer/ easee-home-opladningsstation-sort/p-1043661/]

Proshop. Webasto Pure 22 kW Type 2 Black Edition 2020 [Available from: https://www.proshop.dk/Elbil-Ladere/WebastoPure-22-kW-Type-2-Black-Edition/2827465]

Radonjic-Simic M, Pfisterer D (2019) A decentralized business ecosystem model for complex products. In: Patnaik S, Yang X-S, Tavana M, Popentiu-Vlădicescu F, Qiao F (eds) Digital business: business algorithms, cloud computing and data engineering. Springer International Publishing, Cham, pp 23-52. https://doi.org/10.1007/978-3-319-93940-7_2

Rong K, Hu G, Lin Y, Shi Y, Guo L (2015) Understanding business ecosystem using a 6C framework in internet-of-things-based sectors. Int J Prod Econ 159:41-55. https://doi.org/10.1016/j.ijpe.2014.09.003

Rong K, Shi Y (2015) Business ecosystems: constructs, configurations, and the nurturing process, 1st edn. Palgrave Macmillan, UK, p 263

skat.dk. E.A.4.6.3.2 Godtgørelse af afgift af elektricitet 2020 [Available from: https://skat.dk/skat.aspx?oid=2062223] 
Skovmose P. Elsystemet i Danmark: experimentarium; 2010 [Available from: https:/www.experimentarium.dk/klima/ elsystemet-i-danmark/]

Smart Grid Coordination Group (2012). Smart Grid Reference Architecture; Technical Report; CEN-CENELEC-ETSI: Brussels, Belgium

Smart Grid Coordination Group (2014) Document for the M/490 Mandate: Smart Grids Methodology and New Applications. Technical Report; CEN-CENELEC-ETSI: Brussels, Belgium

Sperto. Danmarks åbne ladenet 2020 [Available from: https:/www.sperto.dk]

Tanev S, Thomsen MS, Ma Z (2010) Value co-creation: from an emerging paradigm to the next practices of innovation. Proceedings of the 3rd ISPIM Innovation Symposium, Quebec City (Canada). In Host Publication ISPIM

Tesla. Support 2020 [Available from: https://www.tesla.com/da_DK/support/home-charging-installation]

Thansen. Væglader EV Type 2 32A 1 fase 6M 2020 [Available from: https:/www.thansen.dk/bil/udstyr/eludstyr/ev-ladekabeltil-elbil/ev-vaeglader-mode-c-for-bil-m-mode-3-kabe/vaeglader-ev-type-2-32a-1-fase-6m/n-236539181/pn-237359935/ ?gclid=CjwKCAiAy9jyBRA6EiwAeclQhJpvRAhik7Xj8RQwaQaPpo-PKRe54rVoTChA5t8kyG6a__cz6xjDOhoC6IAQAvD_ BwE\&gclsrc=aw.ds]

The Open Group. The TOGAF® Standard, Version 9.2 Overview 2020 [Available from: https:/www.opengroup.org/togaf]

thecharger.dk. Easee Home Ladestation - 22kW - 32A - Type 22020 [Available from: https://thecharger.dk/easee-home-la destation-22kw-32a-type-2]

Tian CH, Ray BK, Lee J, Cao R, Ding W (2008) BEAM: a framework for business ecosystem analysis and modeling. IBM Syst J 47(1):101-114. https://doi.org/10.1147/sj.471.0101

True Energy. Intelligent el - Klimavenligt og billigere 2020 [Available from: https://www.trueenergy.dk]

U.S. Department of Defense (2010) The DoDAF Architecture Framework Version 2.02. U.S. Department of Defense, Washington, D.C. U.S. [Available from: https://dodcio.defense.gov/Library/DoD-Architecture-Framework/]

Vargo SL, Lusch RF (2016) Institutions and axioms: an extension and update of service-dominant logic. J Acad Mark Sci 44(1): 5-23. https://doi.org/10.1007/s11747-015-0456-3

Wieringa RJ, Engelsman W, Gordijn J, lonita D (2019) A business ecosystem architecture modeling framework. In: 2019 IEEE 21 st Conference on Business Informatics (CBI)

Wolsink M (2012) The research agenda on social acceptance of distributed generation in smart grids: renewable as common pool resources. Renew Sust Energ Rev 16(1):822-835. https://doi.org/10.1016/j.rser.2011.09.006

Zhang M, Guo Z, Zheng H, Zuo W (2016) Research on the innovation of business ecosystem model in China's online food reservation market at sharing economic era. WHICEB

\section{Publisher's Note}

Springer Nature remains neutral with regard to jurisdictional claims in published maps and institutional affiliations.

\section{Submit your manuscript to a SpringerOpen ${ }^{\circ}$ journal and benefit from:}

- Convenient online submission

- Rigorous peer review

- Open access: articles freely available online

- High visibility within the field

- Retaining the copyright to your article

Submit your next manuscript at $\boldsymbol{\nabla}$ springeropen.com 